University of Rhode Island

DigitalCommons@URI

Open Access Master's Theses

1981

\title{
Potato Waste as a Substrate for Single Cell Protein and Enzyme Production
}

Adilades A. Arenas Santiago

University of Rhode Island

Follow this and additional works at: https://digitalcommons.uri.edu/theses

\section{Recommended Citation}

Arenas Santiago, Adilades A., "Potato Waste as a Substrate for Single Cell Protein and Enzyme Production" (1981). Open Access Master's Theses. Paper 1388.

https://digitalcommons.uri.edu/theses/1388

This Thesis is brought to you for free and open access by DigitalCommons@URI. It has been accepted for inclusion in Open Access Master's Theses by an authorized administrator of DigitalCommons@URI. For more information, please contact digitalcommons-group@uri.edu. 
POTATO WASTE AS A SUBSTRATE FOR

SINGLE CELI PROTEIN AND ENZYME

PRODUCTION

BY

ADALIDES A. ARENAS SANTIAGO

A THESIS SUBMITTED IN PARTIAL FULFILLMENT

OF THE REQUIREMENT FOR THE DEGREE OF

MASTER OF SCIENCE

IN

CHEMICAI ENGINEERING

UNIVERSITY OF RHODE ISLAND

1981 
MASTER OF SCIENCE THESIS

OF

ADALIDES A. ARENAS S.

Approved:

Thesis Commitee:

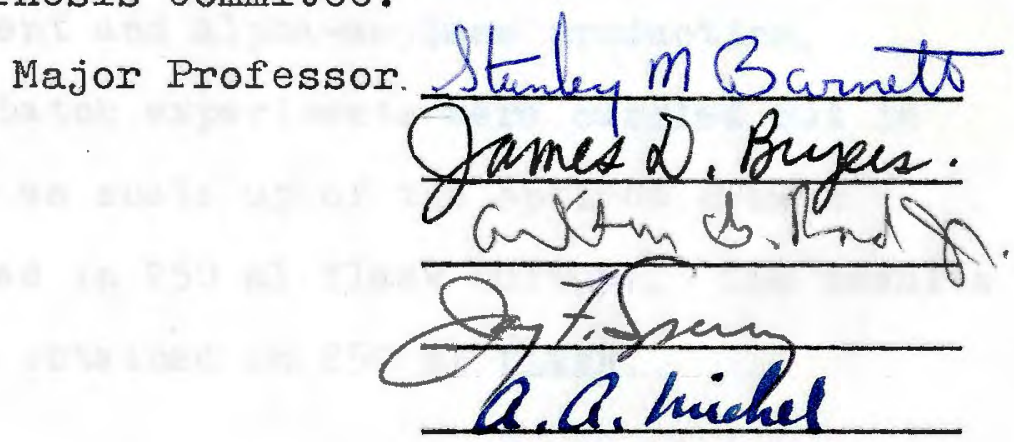

Dean of the Graduate

School

UNIVERSITY OF RHODE ISLAND

1981 


\section{ABSTRACT}

The feasibility of using potato wastes as substrate for single cell protein (SCP) and extracellular enzyme production by Pleurotus ostreatus was studied in submerged culture.

Cell mass yield and enzyme production of $\underline{P}$. ostreatus were studied as a function of (1) substrate concentration, (2) source of nitrogen, (3) temperature, (4) $\mathrm{pH}$ and (5) the addition of sodium bisulfite on the medium. The fermentation process was carried out to batch cultures in $250 \mathrm{ml}$ flasks. Protein content on a dry cell mass basis, alphaamylase activity and reducing sugar content in the broth were determined in all the growth steps of $\underline{P}$. ostreatus. Ammonium sulfate was found to be the better nitrogen source than either urea or ammonium nitrate for cell mass yield, protein content and alpha-amylase production.

Two additional batch experiments were carried out in a 5-liter fermenter as scale up of the optimum growth conditions determined in $250 \mathrm{ml}$ flask culture. The results were close to those obtained in $250 \mathrm{ml}$ flask. 
DEDICADO

A MIS PADRES, ESPOSA, HIJOS Y HERMANOS

CON AMOR Y GRATITUD 


\section{ACKNOWLEDGEMENTS}

The author is indebted to his adviser, Dr. Stanley M. Barnett, for suggesting this topic, for his help and encouragement at every stage of this research. Dr. Arthur G. Rand Jr., for his valuable advise and for the use of his lab and equipment. Dr. Chester W. Houston for his time and technical assistance.

Thanks are due to the Universidad Nacional de San Cristobal de Huamanga - Ayacucho - Peru; Iatin American Scholarship Program of American University and University of Rhode Island for allowing the author to study in this country. 
ABSTRACT $\quad \ldots \ldots \ldots \ldots \ldots \ldots \ldots \ldots \ldots \ldots \ldots \ldots \ldots \ldots \ldots \ldots$ ACKNOWLEDGEMENTS $\ldots \ldots \ldots \ldots \ldots \ldots \ldots \ldots \ldots \ldots$ iv IIST OF TABLES $\ldots \ldots \ldots \ldots \ldots \ldots \ldots \ldots \ldots \ldots \ldots \ldots . \ldots . . \ldots$ IIST OF FIGURES $\ldots \ldots \ldots \ldots \ldots \ldots \ldots \ldots \ldots \ldots \ldots \ldots$ vii INTRODUCTION $\quad \ldots \ldots \ldots \ldots \ldots \ldots \ldots \ldots \ldots \ldots \ldots \ldots \ldots$ THEORY AND IITERATURE SURVEY $\ldots \ldots \ldots \ldots \ldots \ldots \ldots \ldots$ MATERIALS AND METHODS $\ldots \ldots \ldots \ldots \ldots \ldots \ldots \ldots \ldots \ldots$ RESUITS AND DISCUSSIONS $\ldots \ldots \ldots \ldots \ldots \ldots \ldots \ldots . \ldots . \ldots$ CONCLUSIONS $\ldots \ldots \ldots \ldots \ldots \ldots \ldots \ldots \ldots \ldots \ldots \ldots \ldots \ldots$ RECOMIENDATIONS $\quad \ldots \ldots \ldots \ldots \ldots \ldots \ldots \ldots \ldots \ldots \ldots . \ldots$ BIBLIOGRAPHY $\ldots \ldots \ldots \ldots \ldots \ldots \ldots \ldots \ldots \ldots \ldots \ldots \ldots \ldots . \ldots 1$ APPENDIX 


\section{IIST OF TABLES}

PAGE

Table 1.- Possible Substrate for SCP Production .... 6

Table 2.- Average Potato Production of the World .... 13

Table 3.- Proximate Analysis of White Potatoes ..... 18

Table 4.- Essential Amino Acid Distribution in

Protein Sources $\ldots \ldots \ldots \ldots \ldots \ldots \ldots \ldots . \ldots 24$

Table 5.- Results of Substrate Concentration Va-

riation Studies of $\underline{\underline{P}}$. Ostreatus grown

on Potato Wastes.

Table 6.- Results of Different Nitrogen Source

Variation Studies of $\underline{P}$. Ostreatus

grown on Potato Wastes ............. 58

Table 7.- Results of Temperature Variation Studies

of $\underline{P}$. Ostreatus grown on Potato Wastes

Table 8.- Results of Sodium Bisulfite Variation

Studies of $\underline{P}$. Ostreatus grown on Potato

Wastes

68

Table 9.-Results of $\mathrm{pH}$ Variation Studies of $\underline{P}$.

Ostreatus grown on Potato Wastes

73

Table 10.- 5-Iiter Fermenter Studies

74

Table 11.-P. Ostreatus grown on Different Substrates

77 


\section{LIST OF FIGURES}

PAGE

Fig. 1.- General scheme for SCP production from agricultural wastes

Fig. 2.- Scheme for yeast-starch SCP process ...... 11

Fig. 3.- Scheme for fungus-starch SCP process ..... 12

Fig. 4.- Iongitudinal section of a Russet Burbank

potato showing principal structural

features $\ldots \ldots \ldots \ldots \ldots \ldots \ldots \ldots \ldots \ldots \ldots \ldots$

Fig. 5.- Molecular structure of starch ......... 20

Fig. 6. - - ostreatus growth on $1 \%$ glucose

concentration.

Fig. 7.- P. ostreatus growth on $1 \%$ substrate concentration

Fig. 8. - . ostreatus growth on $2 \%$ substrate concentration

Fig. 9.- - ostreatus growth on $3 \%$ substrate concentration

Fig.10. - P. ostreatus growth on $4 \%$ substrate concentration

Fig.11.- P. ostreatus growth using ammonium nitrate as nitrogen source

Fig.12.- P. ostreatus growth using urea as nitrogen source 
Fig. 13.- Comparison of cell weight obtained using different nitrogen sources .............. 55

Fig. 14.- P. ostreatus growth using ammonium nitrate as nitrogen source plus sulfuric acid

56

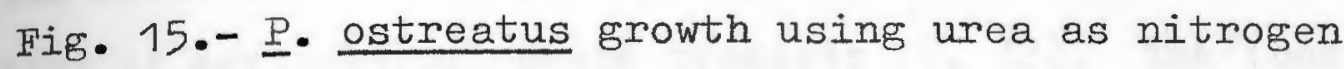

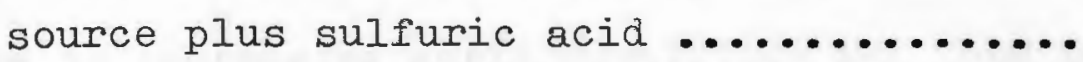

Fig. 16.- P. ostreatus growth on $1 \%$ substrate



Fig. 17. - P. ostreatus growth on $1 \%$ substrate concentration at $30^{\circ} \mathrm{C}$

Fig. 18. - P. Ostreatus growth on $1 \%$ substrate concentration and 50 ppm $\mathrm{NaHSO}_{3}$

Fig. 19.- P. ostreatus growth on $1 \%$ substrate concentration and $100 \mathrm{ppm} \mathrm{NaHSO}$

Fig. 20.- - ostreatus growth on $1 \%$ substrate concentration and $150 \mathrm{ppm} \mathrm{NaHSO}_{3} \ldots \ldots$.

Fig. 21.- P. ostreatus growth on $1 \%$ substrate concentration at $\mathrm{pH} 4.5$

Fig. 22.- P. ostreatus growth on $1 \%$ substrate concentration at $\mathrm{pH} \quad 6.0 \ldots \ldots \ldots \ldots$

Fig. 23. - P. ostreatus growth on $1 \%$ substrate concentration at $\mathrm{pH} \quad 8.0 \ldots \ldots \ldots \ldots$ 


\section{INTRODUCTION}

Recently, there has been considerable emphasis on the world food shortage, energy crisis and the availability of agricultural waste products $(9,32)$. The food shortage due to increasing world population and food production has remained constant over the years. In many of the developing countries, where two-thirds of the world's population reside, the relationship between food availability and rising population is increasingly perilous. Some countries have already reached crisis proportions, where a great part of the population suffers poor nutrition or malnutrition: especially protein malnutrition (e.g., Asia, S.E. Asia, India, Africa, Central America, South America).

Political instability is going to get worse, not better, if proper actions are not taken by governments or world organizations $(10,20,21)$ to alleviate these nutritional conditions.

Protein can be obtained from several sources. These sources are classified under the following three main headings:

1. traditional agricultural and fisheries systems

2. "non conventional" or other biological systems

3. chemical and biochemical syntheses 
Traditional or conventional agricultural and fisheries systems yield protein from animal (meat and milk), plants (grains, legumes, cereals, seeds, roots, etc.) and fish (fish and others). Plants convert inorganic nitrogen into protein but most animals cannot, except for ruminants that are able to convert urea into protein. Technology (e.g., fertilizer, equipment, improved genetic changes and good management) has improved protein yield but competition for grains and other agricultural products exists between people and animals. Animal proteins are of good quality but are too costly to be a major source of protein for a considerable proportion of the world's population. Moreover, world fish catches are reaching or exceeding the natural limits for many species. Recently the escalating cost of petroleum has increased the price of fertilizer and other agricultural inputs to achieve greater food production (4).

Proteins coming from chemical and biochemical syntheses are expensive due to the continuous rising cost of petroleum since most of the raw materials used are derived from petroleum.

In addition to the above considerations, availability and disposal of agricultural waste products have created pollution problems. New protein sources from agricultural wastes could be an alternative for helping to solve food, energy, and pollution problems. 


\section{THEORY AND IITERATURE SURVEY}

Single Cell Protein. - Because the words "microbial" and "bacterial" have somewhat undesirable connotations with respect to food, the term "Single Cell Protein" was proposed to cover the concept of utilizing microcrganism as food (62). It is a term used to describe the protein contained in microorganisms capable of independent existence as single cells, in particular yeasts, bacteria, algae, and fungi.

Yeasts.- Several species have been studied by researchers in order to use as food, however two of them have been the most used for human food and animal feed, Candida utilis, also known as tomla yeast and Saccharomyces carlsbergensis or brewer's yeast. The main disadvantage to using yeasts as human food is the high level content of nucleic acids which may cause certain physiological problems because uric acid, the final metabolic product of the purines contained in nucleic acids, is relatively insoluble $(57,66,69)$.

Algae.- Members of Chlorella (green algae) and Spirulina (blue-green algae) have been studied extensively as producers of edible protein. These species may contain $50 \%$ and $60 \%$ protein respectively, on a dry weight basis. Algal protein contains all of the essential amino acids 
but it is, however, low in sulfur-containing amino acids, particularly methionine (10).

Bacteria.- Due to their ability to use petroleum hydrocarbons as carbon sources, species of Nocardia, Mycobacterium, Micrococcus, Bacillus, and Pseudomonas are being investigated for protein production and pollution control.

Fungi.- Fungi have been used as food and in food processing. The macroscopic sporophores have been advocated as a potentially valuable source of protein for man and domestic animals (25). Most fungi have been obtained by solid state fermentation processes.

Researchers have proposed that a large amount of food protein can be produced by growing microorganisms on a wide variety of substrates. These substrates are classified into three categories in Table $1(15,29)$ : materials that have a high value as a source of energy or are derived from such materials; materials that are essentially waste and should be recycled back into the ecosystem by some non-polluting method; and materials that can be derived from plants and hence are a renewable resource.

From an economic and energy standpoint, and availability, the last two categories have an advantage over oil or its derived products due to constantly rising price of oil.

In addition to the oil crisis, protein from microorganisms which were grown using hydrocarbons as substrate has 
some formidable obstacles to overcome before this protein will be accepted for human consumption. The main problem with these substrates is the possible contamination of the feedstock with carcinogenic polycyclic aromatics, such as benzopyrene, which are known to be present in crude oil (46).

Wastes and by-products have limited uses in single cell protein production. Domestic wastes have inherent dangers, various chemical residues could cause acute or chronic poisoning if they were taken up by microorganisms. Waste paper, which can easily be handled separately from other domestic wastes, has been used successfully, but may also be the source of some toxic materials. $(44,64)$. Photosynthetically-produced materials are available in very large quantities and have the virtue of being renewable. They are mainly composed of cellulose and starches. $(46,60,64)$.

Microbial protein production may become a potential protein source for the world's growing human population and animals for the following reasons $(33,43,46)$ :

1.- Substrate for single cell protein production can be cheap, e.g. agricultural waste products, in comparison with conventional methods of production from animals, fish and plants.

2.- Quick growth because the life cycles of microorganisms are relatively short; some yeasts can double 
Table 1.- Possible Substrates for Single Cell Protein.

Substrate

Natural gas

n-Alkanes

Gas oil

Me thanol

Ethanol

Acetic Acid

Baggase

Citrus Waste

Whey

Sulfite water Liquor

Molasses

Animal Manure

Sewage

Carbon Dioxide

Starch

Sugar

Cellulose

\section{Classification}

Energy source

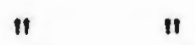

II



"11

Energy source or waste Mat. Waste Materials

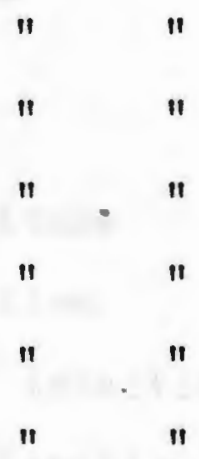

Waste or Renewable Resource Renewable Resource Material

II

II

II

II
II

Ref. $(15,29)$. 
their mass in about 30 minutes.

3.- The conditions of growth of microorganism for SCP production are easy to control.

4.- Protein content of microorganisms is high, some contain up to $50 \%$ protein on a dry basis.

5.- Production of protein directly from inorganic ammonium salt is possible.

6.- It can be produced in continuous processes independently of climate changes and in plants that require small amount of land.

The principal and desirable factors in selecting microorganisms as food or feed are (48)

I.- Technical Factors

A.- Rapid growth

B.- Simple media

C.- Suspension culture

D. - Simple separation

E.- Resistance to infection

F.- Efficient utilization of energy source.

G.- Disposable efluent.

II.- Physiological and Organoleptic Factors.

H. - Capable of genetic modification

I. - Nontoxic

J.- Good taste

K.- High digestibility

I.- High nutrient content 
M. - Protein, fat and carbohydrate content of high quality.

N.- Economically suitable.

According to the materials used as substrates and microorganism used in the fermentation process for SCP production, several processes are available and are shown on Figures $1-3$.

POTATO WASTE AS A SUBSTRATE FOR SINGIE CELI PROTEIN PRODUCTION.

Historically, the potato, Solanum tuberosum, has been a reliable food source for man and animal. Originally from Peru it is now spread around the world and presently it is the fourth largest world food crop, following wheat, corn and rice. It is one of the most economical food sources per unit area. Its yield per hectare ranges from $25000 \mathrm{Kg}$ to 40000 depending upon soil quality, fertilizer, climate and available technology. After harvesting, the potato is highly perishable. Proper storage and transport are needed to bring this crop from the farm to the market. During this period a great deal of potatoes are wasted due to spoilage by microorganisms, insect damage, sprouting, mechanical damage or poor handling. In addition to this wastage, potatoes which are too small or mechanically damaged during the harvesting process and are not used in any potato process- 
ing (drying, chip potato, mash potato, starch, etc.) are also wasted. These wastes reach from $5 \%$ to $7 \%$ of the total crop plus $3 \%$ to $5 \%$ due to improper size and mechanical damage on the farm. In the third world countries (developing countries or under developed countries) where there is neither technology for processing nor preserving this crop, the waste is at the 15 or $20 \%$ level (21). (see Table 2).

Structure and Chemical Composition of the Potato Tuber.

The tuber itself is essentially an abruptly thickened underground stem closely resembling the aerial stem of the plant (3). Figure 4 shows the organization of the principal internal tissues of the mature tuber. The outer skin consists of a layer of corky periderm, which appears to serve the purpose of retarding loss of moisture and resisting attack by fungi.

Underlying the periderm is the cortex, a narrow layer of parenchyma tissue. Vascular storage parenchyma which is high in starch content, lies within the shell of the cortex. Forming a small central core but radiating narrow branches to each of the eyes, is the pith, sometimes called the water "core".

Proximate Analysis and Mineral Content.

It is difficult to obtain a clear picture of the composition of the potato. It varies with variety, area of growth, cultural practices, maturity at harvest, subsequent storage history and the methods of analysis used (42). 
NON FERMENTABIE

SUBSTANCES

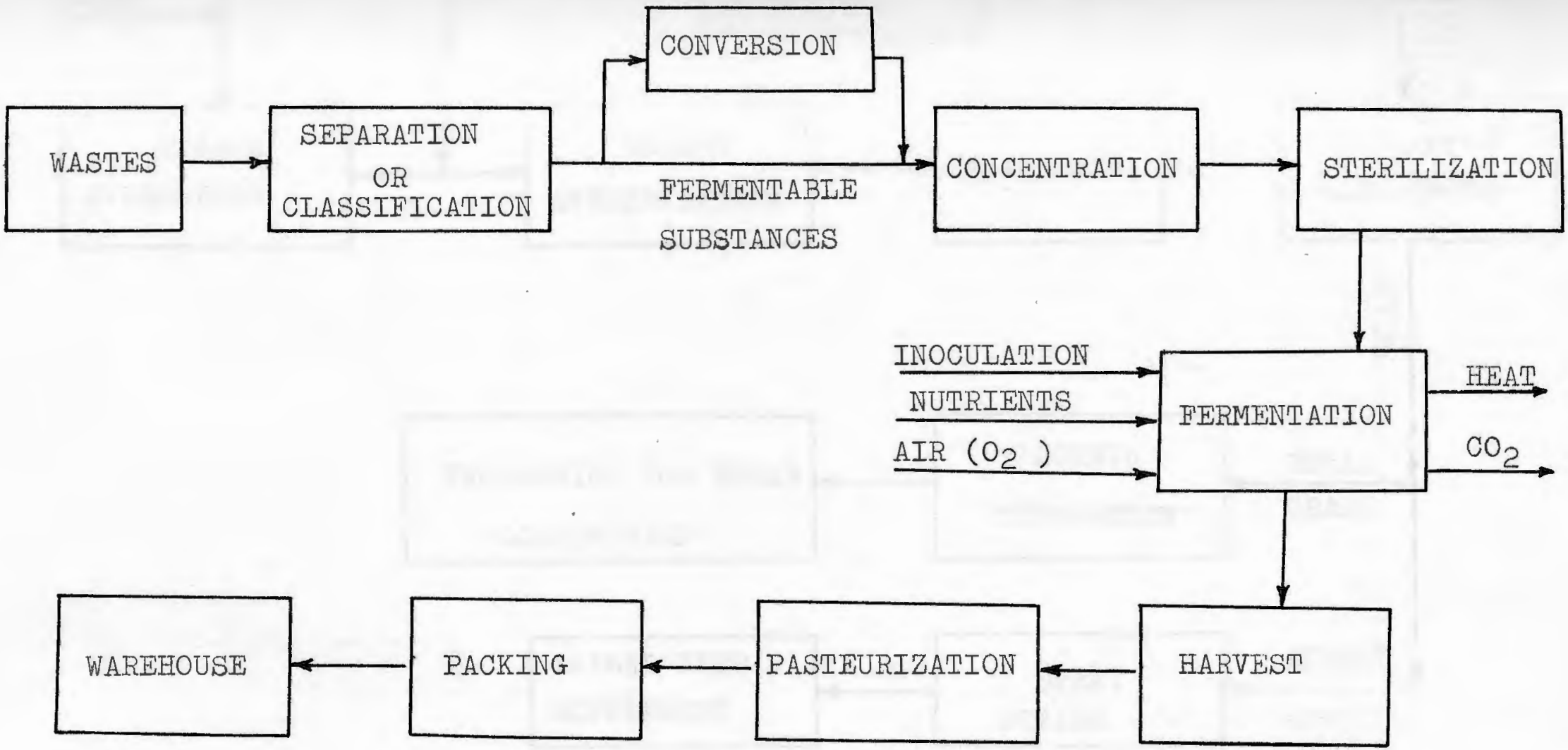

FIG. 1 - GENERAI SCHEME FOR SINGIE CELI PROTEIN PRODUCTION FROM AGRICUITURAL WASTE MATERIALS (15) 


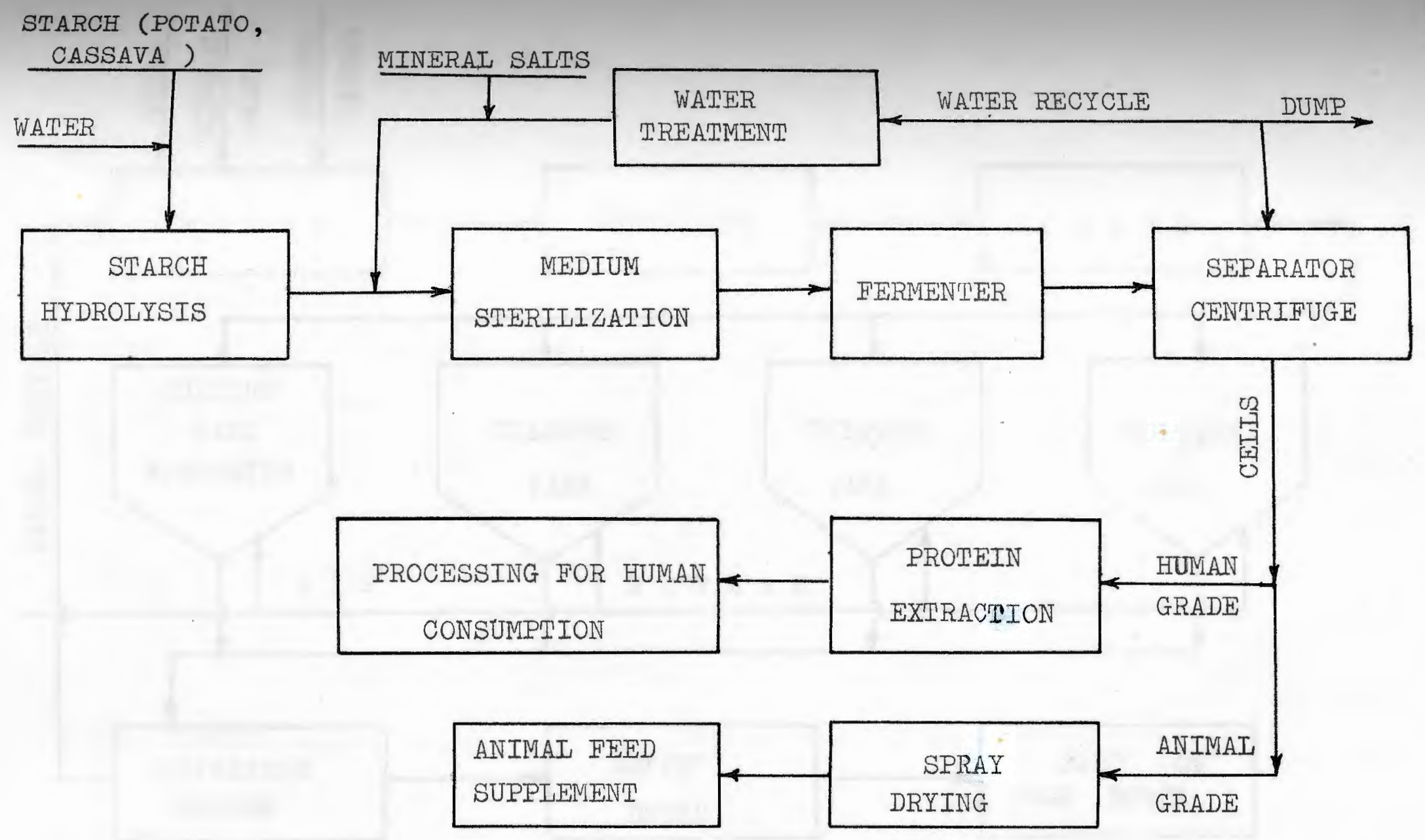

FIG. 2 - SCHEME FOR YEAST-STARCH SINGLE CELI PROTEIN PROCESS (46) 


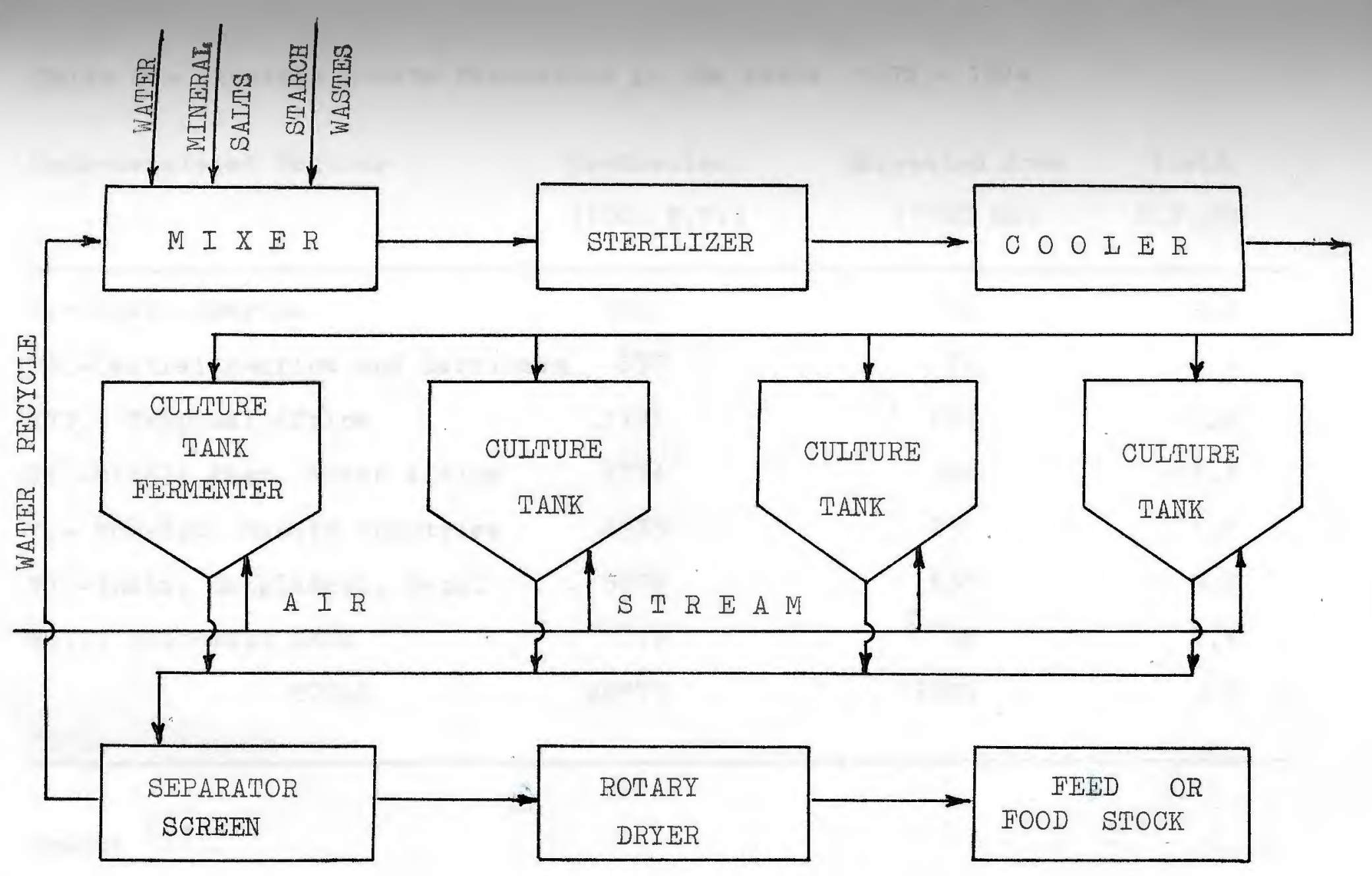

FIG. 3.- SCHEME FOR FUNGUS-STARCH SINGLE CELI PROCESS (25). 


\begin{tabular}{|c|c|c|c|}
\hline Underdeveloped Regions & Production & Harvested Area & Yield \\
\hline & $(1000 \mathrm{M} \cdot \mathrm{T})$. & $(1000 \mathrm{Ha})$ & M.T./Ha \\
\hline I.- South America & 7921 & 939 & 8.4 \\
\hline II.-Central America and Carribean & 657 & 70 & 9.4 \\
\hline III.- Tropical Africa & 1121 & 209 & 5.4 \\
\hline IV.-Middle East, North Africa & 1734 & 156 & 11.1 \\
\hline V.- Non-Arab Muslim Countries & 2933 & 259 & 11.3 \\
\hline VI.-India, Bangladesh, Nepal & 5899 & 639 & 9.2 \\
\hline \multirow[t]{2}{*}{ VII. - Southeast } & 712 & 96 & 7.4 \\
\hline & 20977 & 2281 & 9.2 \\
\hline
\end{tabular}

Source (21). 
Table 2.- Cont. Average Potato Production in the World 1972 - 1974.

Developed Countries

$$
\begin{array}{lcc}
\text { Production } & \text { Harvested Area } & \text { Yield } \\
(1000 \text { M.T. }) & (1000 \mathrm{Ha}) & \text { M.T. } / \mathrm{Ha}
\end{array}
$$

Canada

Denmark

Germany

Netherlands

Sweden

Switzerland

United Kingdom

United States of America

Total

Other Countries

\begin{tabular}{|c|c|c|c|}
\hline & 89077 & 7992 & 11.2 \\
\hline & 50888 & 2668 & 19.1 \\
\hline & 35360 & 3765 & 9.4 \\
\hline & 54454 & 3601 & 15.1 \\
\hline TOTAL & 229779 & 18026 & 12.7 \\
\hline
\end{tabular}

U.S.S.R.

Poland

China

others

TOTAI
2202

785

14420

5649

20.6

25.3

29.7

36.4

24.1

36.2

29.7

26.6

28.6

45975

1608

11.2

15.1

12.7

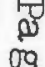

OQ⿻

$\vec{A}$ 
Some workers have analyzed the whole potato, while others have used peeled tubers. Table 3 gives proximate analysis of a whole potato.

Starch.- The constituents of potato about which most is known are the carbohydrates comprised largely of starch. Starch, comprising from $65 \%$ to $80 \%$ of the dry weight of potato tuber, is calorically the most important nutritional component. In the raw tuber starch is present as microscopic granules in the leucoplasts lining the interior of the walls of the cells of the parenchyma tissue. The granules are ellipsoidal in shape, about 100 micrometers by $60 \mu_{m}$ on the average. They are thus much larger than the average starch granules of the cereal grains. The starch granule resembles an oyster shell in appearance due to apparent striations on the surface.

There is a highly significant correlation between the starch content of the raw tuber and the textural qualities such as mealiness, consistency, sloughing, and sogginess. During the cooking process water is taken up by the starch granule which then starts to swell. In the range of 147 to $160^{\circ} \mathrm{F}$, the starch begins to gelatinize. In potatoes of high starch content the cells tend to round off and separate as a result of swelling of the gelatinized starch, resulting in a mealy texture.

The chief constituent of starch grain yields glucose when hydrolized and is called starch. The material is 
actually a mixture of substances of different structure and properties. When starch is treated with boiling water, a substance in the center of the grain passes into the solution, but the greater part of the grain is not soluble. This insoluble portion absorbs water and swells to form an elastic sphere, and whole the mass becomes starch paste. While both the soluble and insoluble fraction are mixed, it is customary to refer to the soluble component as "amylose" and the insoluble part as "amylopectin". These two main components of starch are present in a ratio of $1: 3$ in potato. Amylose.- Generally, amylose is present in starch at from 20 to $28 \%$ of total weight. An amylose polymer consists of 250 to 300 D-glucose molecules linked by alpha1-4-glucosidic bonds (Figure 5). These polymers tend to twist the chain into a helix. In amylose, the majority of the units are similarly connected by alpha-1-4glucosidic bonds, but there are occasional alpha-1-6glucosidic bonds (53).

Both granules and the colloidal solutions starch react with iodine to give a blue color. This is chiefly due to amylose, which forms a deep blue complex (71). Amylopectin.- Amylopectin is a branched-chain glucose polymer in which the alpha-1-4- linkages are branched by an alpha-1-6- linkage (Figure 5) on the average of every 20 glucosyl residues. Each of these small branches 


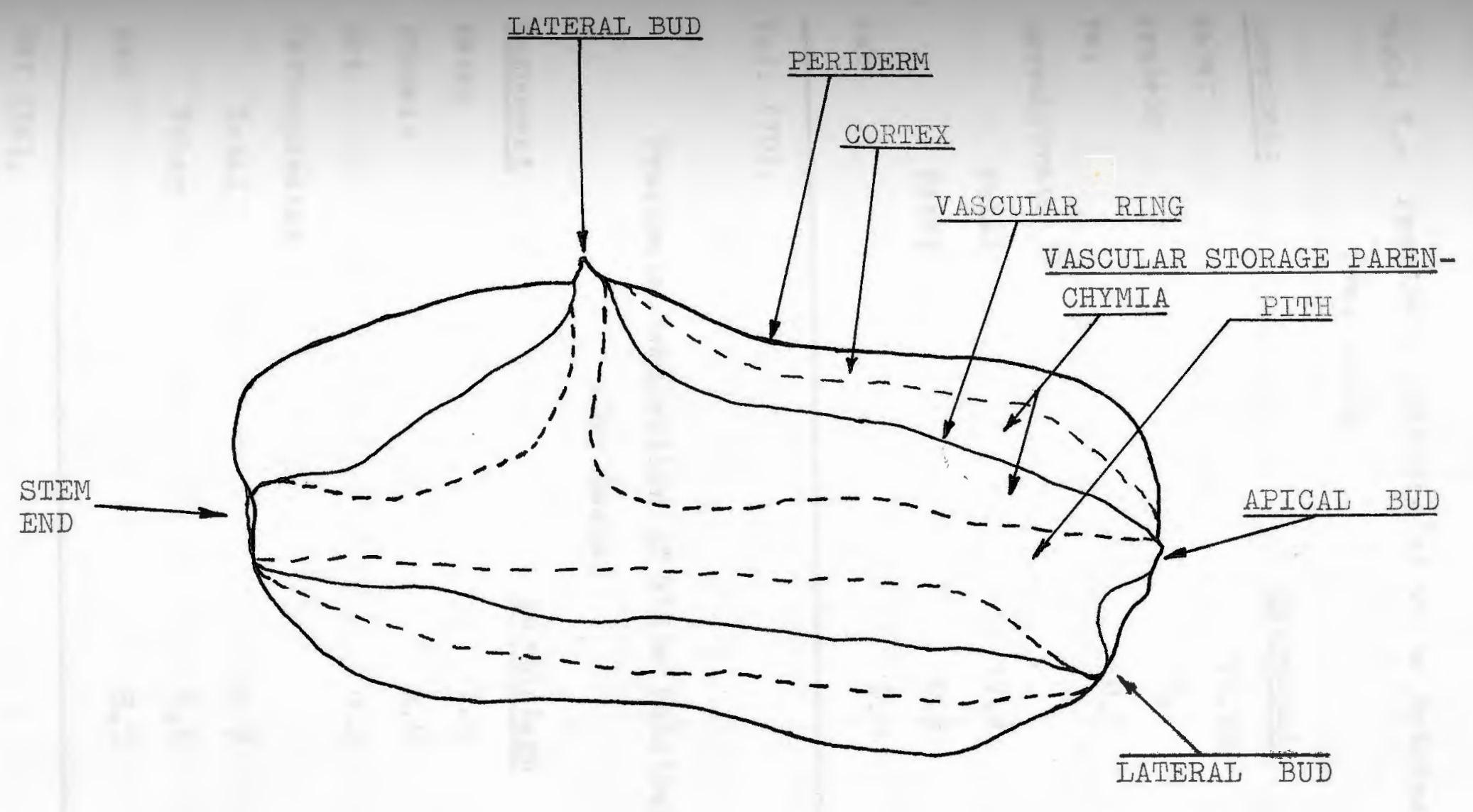

FIG. 4 - - LONGITUDINAI SECTION OF A RUSSET BURBANK POTATO SHOWING PRINCIPAI STRUCTURAI FEATURES 
Table 3.- Proximate Analysis of White Potatoes (Wet Basis)

Component

Water

Protein

Fat

Carbohydrate

Total

Fiber

Ash

Ref. (70).
Percentage

$79.8 \%$

2.1

0.1
17.1

0.5

0.9

Proximate Composition of White Potatoes (Dry Basis)

Component

Water

Protein

Fat

arbohydrates

Total

79.9

Fiber

Ash

$\operatorname{Ref}(36)$.

1.6

3.7
Percentage

7.6

8.0

0.8 
resembles the larger amylose chains, but the molecules are joined together in such a way that the free reducing group of the end glucose unit glucosidically linked through the sixth glucose carbon in an adjoining chain.

The hydrolysis reaction of amylose may be followed with iodine according to the scheme:

Iodine reaction

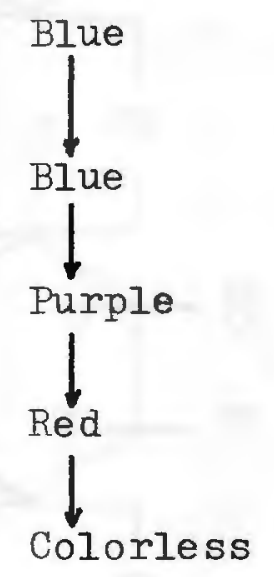

Course of hydrolysis

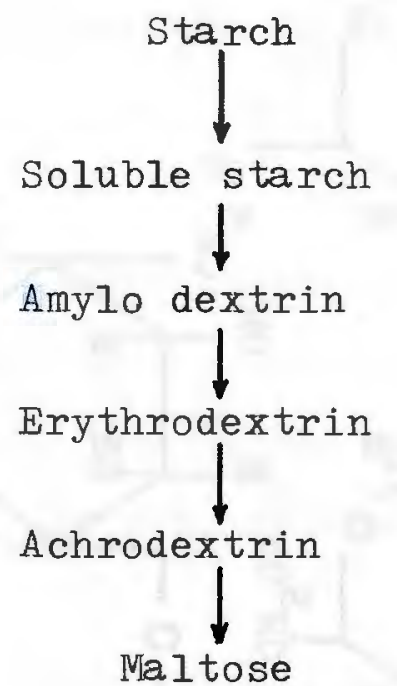

Sugar.- The sugar content of potatoes may vary from Inly trace amounts to as much as $10 \%$ of the dry weight of the tuber. The two main factors which influence sugar content during the post-harvest storage are variety and temperature.

Non-Starch Polysaccharides.- Small amounts of the following occur in potatoes primarily in the cell walls 

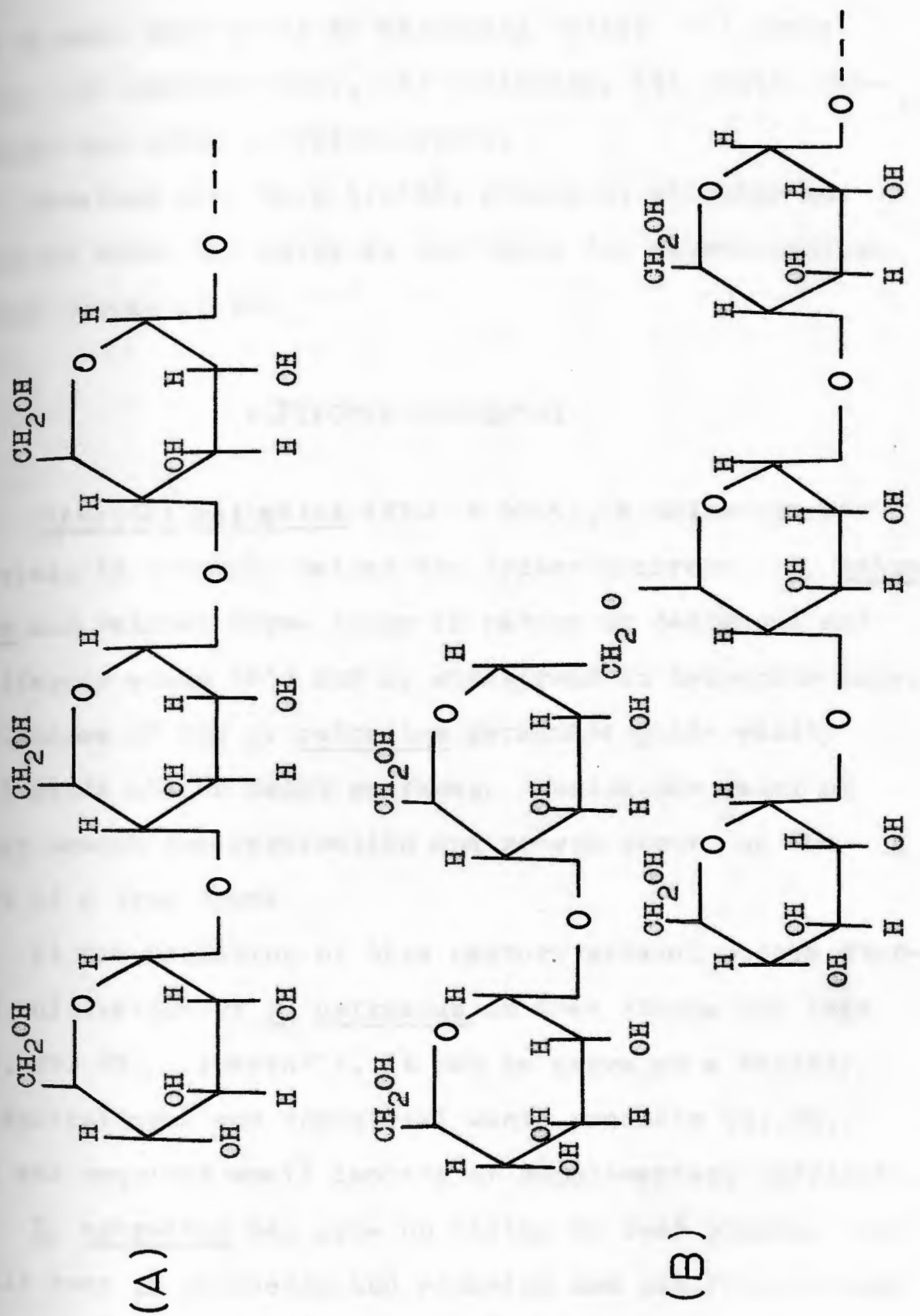

Фิ

FIG. 5 - Starch Structure

(A) Amylose

(B) Amylopectin 
and between cell walls of adjoining cells: (1) crude fiber, (2) hemicellulose, (3) cellulose, (4) pectic substances and other polysaccharides.

Potatoes also have lipids, minerals, vitamins and proteins which can serve as nutrients for microorganisms during fermentation.

\section{PLEUROTUS OSTREATUS}

\section{Pleurotus ostreatus (ATCC \# 9515), a white-spored} species, is commonly called the oyster mushroom. P. ostreatus and related forms occur in nature on deciduous and coniferous woods (65) and is widespread in temperate zones. The spores of the $\underline{P}$. ostreatus germinate quite easily in liquids and on moist surfaces. During the rainy or foggy season the germination and growth occur on the bark of a tree trunk.

At the beginning of this century several people started cultivation of $\underline{P}$. ostreatus on tree stumps and logs $(18,45,55)$. Presently, it can be grown on a variety of agricultural and industrial waste products $(5,26$, 38) and requires small amounts of supplementary nutrients.

P. ostreatus can grow on living or dead plants, typically poor in nutrients and vitamins and can fix nitrogen from the air $(23,24,59,12)$.

P. ostreatus is among the parasites or primary agents of decomposition. It has the ability to directly break 
down cellulose and lignin-bearing materials without chemical or biological preparations. The metabolism and growth conditions in solid state fermentation of cellulosic materials has been studied by several researchers $(38,40,75$, 76). However, $\underline{P}$. ostreatus grows well and rapidly in submerged culture and was found to produce a high concentration level of the extracellular enzyme lactase when cellulosic materials were used as a substrate (63).

P. ostreatus has several notable features for a human food: good taste, nice odor, texture, digestibility and nutritive value. $(22,25,51)$. Its nutritive value is associated with its high protein content on a dry basis, and complete amino acid distribution (22) compared with milk and beef (Table 4). It constitutes a good source of niacin, riboflavin, vitamin C, folic acid, calcium, phosphorus and potassium (51). 
Page 23

Table 4.- Essential amino acid distribution in protein sources, expressed as per cent of total protein (22).

Amino acid

Isoleucine

Leucine

Iysine

Phenylalanine

Cysteine

Methionine

Threonine

Firyptophan

Valine

Argenine

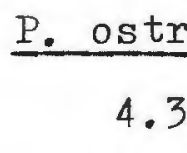

7.7

6.0

3.4

0.7

1.1

5.8

1.0

6.4

4.0
$\underline{B e e f}$

6.0

8.0

10.0

5.0

1.2

3.2

5.0

1.4

5.5

7.7
Cow's milk

7.8

11.0

8.7

5.5

1.0

3.2

4.7

1.5

7.1

4.2

Source (22). 
Table 4 (b).- Amino acid distribution of P. ostreatus expressed as per cent of total protein.

Amino acid

4spartic acid

Threonine

Serine

Glutamic acid

Proline

Glycine

Alanine

Valine

Methionine

Leucine

Isoleucine

Tonylalanine

tyrosine

Histidine

Iysine

yptophan

trgenine
P. ostreatus

7.17

3.57

4.50

19.48

4.71

3.80

4.72

1.60

2.33

4.50

3.13

2.90

1.83

5.91

4.94

0.57

14.4
FAO standard

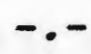

2.80

-*-

$-.-$

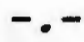

$-.-$

-. -

4.20

2.20

4.80

4.20

2.80

2.80

-. -

4.20

$-.-$

-.

Ref. (63). 
Microorganism. - All experiments were carried out with Pleurotus ostreatus (ATCC 9415). A stock culture was maintained on potato dextrose agar (Difco) at $5^{\circ} \mathrm{C}$. Substrate.- Raw potatoes (cultivated in Russet Burbank, Idaho) were dried at $100{ }^{\circ} \mathrm{C}$ and ground into an average size of 100 mesh (Tyler Scale) powder.

Growth media.- The medium composition was modified from that proposed by Hofsten and Ryden (27).

Component

Ammonium sulfate

F-Asparagine

$\mathrm{CH}_{2} \mathrm{PO}_{4}$

$\mathrm{MgSO}_{4} \cdot 7 \mathrm{H}_{2} \mathrm{O}$

$\mathrm{CaCl}_{2} \cdot 2 \mathrm{H}_{2} \mathrm{O}$

$\mathrm{NaCl}$

$\mathrm{ZnSO}_{4} \cdot 7 \mathrm{H}_{2} \mathrm{O}$

$\mathrm{FeSO}_{4} \cdot 6 \mathrm{H}_{2} \mathrm{O}$

Yeast extract

Potato as substrate.

\section{Amount $(g / 1)$}

4.3

1.0

1.0

0.5

0.1

0.1

0.005

0.005

1.0 
Preparation of Inoculum.- For most of the experiments the flasks containing the sterile medium were inoculated by transferring the microorganism directly from the potato dextrose agar with a loop into $100 \mathrm{ml}$ of the media contained in $250 \mathrm{ml}$ flasks.

For experiments in the 5-liter fermenter an indirect inoculation was made to obtain a uniform inoculum. The mifroorganism was transferred directly into $300 \mathrm{ml}$ of media containing $1 \%$ potato flour in a $500 \mathrm{ml}$ Pyrex flask, using the loop method. After inoculation, flasks and their contents were incubated at $27{ }^{\circ} \mathrm{C}$ in an environmental shaker (New Brunswick Scientific model \# G 26) at 125 RPM for 4 to 5 days. This $300 \mathrm{ml}$ of solution, the microorganism, was transferred into 5 liter of media. The initial pH was adjusted to 5.5 by using $0.1 \mathrm{~N} \mathrm{NaOH}$ or $0.1 \mathrm{~N} \mathrm{HCl}$ solution.

Effects of Substrate Concentration on Fungal Growth Tein Content and Alpha-Amylase Activity.

Potato flour at concentrations of $1 \%, 2 \%, 3 \%$, and $4 \%$ was used. All other conditions remained unchanged ( $\mathrm{pH}=5.5, \mathrm{RPM}=125$, ammonium sulfate as Nitrogen source, $t=27^{\circ} \mathrm{C}$ ). 
Pfect of $\mathrm{pH}$ on Fungal Growth, Protein Content, and -Amylase Activity.

Effects of $\mathrm{pH}$ of the growth medium were observed over the range of $4.5,5.5,6,8$ using $0.1 \mathrm{~N} \mathrm{HCl}$ or $0.1 \mathrm{~N} \mathrm{NaOH}$. other conditions: Temperature $27^{\circ} \mathrm{C}, 125 \mathrm{RPM}$, ammonium sulfate as nitrogen source, $1 \%$ potato flour.

ffect of Nitrogen Sources on Fungal Growth, Protein Sent, and Alpha-Amylase Activity.

The nitrogen source was varied by using ammonium sulfate, urea, ammonium nitrate, urea-sulfuric acid, ammonium nitrate-sulfuric acid. Other conditions: substrate concentration $1 \%, \mathrm{pH}=5.5,125 \mathrm{RPM}$, temperature $27^{\circ} \mathrm{C}$.

Effect of Sodium Bisulfite on Fungal Growth, Protein

Atent and Alpha-Amylase Activity.

Sodium bisulfite solution is used in potato starch manufacture. In order to determine $P$. ostreatus growth, medium solution containing 50, 100 and 150 ppm was used maintaining all other conditions constant. Temperature $27{ }^{\circ} \mathrm{C}, 125 \mathrm{RPM}, \mathrm{pH}=5.5$, and $1 \%$ substrate concentration, ammonium sulfate as nitrogen source.

Effect of Temperature on Fungal Growth, Protein ntent and Alpha-Amylase Activity.

Growth temperature was considered at 20, 27, and $30{ }^{\circ} \mathrm{C}$. All other conditions remained constant. Substrate concentration 1\%, $125 \mathrm{RPM}, \mathrm{pH}=5.5$, ammonium sulfate as 
nitrogen source.

\section{Control. -}

A control using 1\% D-glucose as substitute to potato flour for the carbon source was made.

ANALYTICAL METHODS.

Dry Weight Determination of Fungal Mass and Potato

Rlour Residue

The following procedure was used:

1.0 - Dry filter paper (Whatman \# 2) in an air oven at $105{ }^{\circ} \mathrm{C}$ for 24 hours, then place in desicator.

2.0 - Place a filter paper sheet, previously weighed, in a funnel $\left(W_{1}\right)$.

3.0 - Filter the culture medium through this filter paper (save filtrate solution for enzyme activity and reducing sugar assays).

4.0 - Wash the residue and filter paper with distilled water several times.

5.0 - Place the filter paper and its content in a watch glass and dry at $105{ }^{\circ} \mathrm{C}$ for 24 hours.

6.0 - Cool at room temperature in a desicator and weigh $\left(w_{2}\right)$.

7.0 - Place the filter paper in a flask, pour $30 \mathrm{ml}$ of 2.5\% NaOH solution, mix completely and digest for 


\section{4 hours in a rotary shaker at 125 RPM.}

8.0m-Use another filter paper sheet previously weighed

$\left(W_{3}\right)$ and place it in a funnel. Filter the solution

(save the solution for protein determination Biuret method).

9.0 - Wash the filter paper and its content completely and dry in an air oven for 24 hours at $105{ }^{\circ} \mathrm{C}$. 10.0 - Cool at room temperature and weigh $\left(w_{4}\right)$. The cell weight will be calculated by:

$$
\begin{aligned}
& W_{1}=\text { filter paper weight } \\
& W_{2}=\text { paper plus residue weight } \\
& W_{2}=W_{1}+\text { fungal mass }+ \text { residue weight } \\
& W_{3}=\text { paper weight } \\
& W_{4}=W_{1}+W_{3}+\text { residue weight } \\
& \text { Fungal mass }=W_{2}-W_{4}
\end{aligned}
$$

However this method is not accurate for determining fungal mass, since potato starch (main component of potato) is soluble in $2.5 \% \mathrm{NaOH}$ solution. On the other hand, P. ostreatus is not completely soluble in $2.5 \% \mathrm{NaOH}$ solution, almost 2.3 to $10 \%$ remains insoluble. The solubility is directly related to the fungi maturity. $\underline{P}$. ostreatus grown from 4 to 14 days showed to be more soluble in $2.5 \% \mathrm{NaOH}$ solution, after 14 days of growth the insolubility increased.

It is important to notice that after 4 or 5 days of fermentation almost 98 to $99 \%$ of the potato flour is 
cydrolized, the fungal mass may be estimated without being treated with $2.5 \% \mathrm{NaOH}$ solution.

Biuret Protein Determination. (11).

Protein determination was carried out as follows: Preparation of Biuret Reagent:

1.0 - Place $1.5 \mathrm{~g} \mathrm{CuSO} 4 \cdot 5 \mathrm{H}_{2} \mathrm{O}, 60 \mathrm{~g}$ sodium potassium tartrate $\left(\mathrm{Na} \mathrm{KC}_{4} \mathrm{H}_{4} \mathrm{O}_{6} \cdot 4 \mathrm{H}_{2} \mathrm{O}\right)$, and a stirring bar in a 1 liter volumetric flask.

2.0 - Add $500 \mathrm{ml}$ glass-distilled water to the flask and dissolve above solids.

3.0 - While stirring the contents of the flask vigorously, add $300 \mathrm{ml} 10 \%(\mathrm{w} / \mathrm{v}) \mathrm{NaOH}$.

4.0 - Remove the stirring bar from the flask and bring the volume of liquid to 1 liter with glass-distilled water and mix completely.

\section{Determination of Protein}

1.0 - Place filter paper containing fungal mass in a $250 \mathrm{ml}$ flask and pour $30 \mathrm{ml}$ of $2.5 \% \mathrm{NaOH}$ solution, mix completely and digest for 24 hours at room temperature, and $125 \mathrm{RPM}$.

2.0 - Filter the solution using whatman \#2 filter paper.

3.0 - Pipette duplicate portion of $1 \mathrm{ml}$ of sample solution into a clean test tube. Add $4.0 \mathrm{ml}$ biuret reagent to each tube and vortex the 
mixture for a few seconds to effect thorough mixing of the solution.

4.0 - Incubate the tubes for 30 minutes at room temperature.

5.0 - Measure the color in a Bausch \& Lomb Spectronic 21 Spectrophotometer (Bausch \& Lomb Co., Rochester, N.Y.) at $540 \mathrm{~nm}$.

Calculate the absorbance using the equation:

$$
A=2-\log (\% T)
$$

Standards were prepared by using bovine serum albumin and fit to a straight line by the least square rule (see Appendix A, Fig. A. 1). The protein value of each sample was calculated from this calibration curve.

Protein Determination.- Modified Kjeldahl.

Reagents.-

- Sodium sulfate-anhydrous, low in nitrogen.

- Mercuric sulfate: Dilute $12 \mathrm{ml}$ of concentrated sulfuric acid to $100 \mathrm{ml}$ with distilled water and dissolve 10 grams red mercuric oxide.

- Sulfuric acid, concentrated (95 - 98\%).

- Sodium hydroxide $0.4 \mathrm{M}$, prepared by dilu- 
ting $40 \mathrm{ml}$ of $10 \mathrm{M} \mathrm{NaOH}$ to 1 liter or by dissolving $16 \mathrm{~g}$ in $600 \mathrm{ml}$ of distilled water and brought to 1 liter with distilled water.

- Sodium Hydroxide-sodium iodide prepared by adding $15 \mathrm{~g}$ reagent-grade NaI to one liter of $0.4 \mathrm{M}$ of $\mathrm{NaOH}$.

- 1000 ppm $\mathrm{NH}_{3}$ as $\mathrm{N}$ standard.

\section{Digestion.}

1.0 - Place samples ranging from 0.1 to $0.7 \mathrm{~g}$ into a dry Kjeldahl flask, add $3.0 \mathrm{~g}$ of anhydrous sodium sulfate, $4 \mathrm{ml}$ of mercuric sulfate solution and $20 \mathrm{ml}$ concentrated sulfuric acid to each sample.

2.0 - Boil gently on a digestion rack until the water is boiled off, then slowly increase the heat until the solution is completely clear.

3.0 - Cool the flask and add $5 \mathrm{ml}$ of distilled water to rinse the neck before the contents solidify.

4.0 - Transfer the solution to a $100 \mathrm{ml}$ volumetric flask rinsing the original flask several times with small portion of water and bring to $100 \mathrm{ml}$ with distilled water.

5.0 - Following the same procedure prepare the blanks and ammonium sulfate for checking the percent recovery of nitrogen. 
6.0 - Read the nitrogen content using Orion Research Microprocessor Ionalyzer Model 901 (Orion Research Incorporated, Cambridge, Massachusetts) and the 95-10 ammonia electrode (Orion Research Incorporated, Cambridge, MA.) according to directions given in the manufacturer's instruction manual.

\section{Total Reducing Sugar Determination.}

Total reducing sugar is measured using the dinitroslycylic acid (DNS) method of Miller (50) as modified by Mandels (47).

\section{Reagent}

- Mix:

Distilled water

3,5-Dinitrosalycylic acid

$\mathrm{NaOH}$
$1416.0 \mathrm{ml}$

$10.6 \mathrm{~g}$

$19.8 \mathrm{~g}$

- Dissolve above, then add:

Rochelle salt ( $\mathrm{Na}, \mathrm{K}$ tartrate) $306.0 \mathrm{~g}$

Phenol (melt at $50{ }^{\circ} \mathrm{C}$ )

$7.6 \mathrm{~g}$

$\mathrm{Na}$ metabisulfite $\mathrm{Na}_{2} \mathrm{~S}_{2} \mathrm{O}_{5}$

$8.3 \mathrm{~g}$

Filtered sample is analyzed following this procedure:

- Add $3 \mathrm{ml}$ of DNS to $1 \mathrm{ml}$ of properly diluted sample.

- Heat the mixture in a boiling water bath for 5 min., 
followed by cooling to room temperature using tap water. After cooling, add $15 \mathrm{ml}$ of distilled water to each test tube.

- Following the same steps, prepare glucose standards and a blank.

- Read the percentage transmittance (\%T) on a Bausch \& Lomb Spectronic 21 Spectrophotometer (Bausch \& Lomb Co., Rochester, N.Y.) at 550 nm. (See Appendix A; Fig. A.2).

\section{Glucose Concentration Determination.}

Glucose concentration was determined with a Y S I Model 23 A Glucose Analyzer (Yellow Spring Instrument, Co. Yellow Spring, Ohio.) (6).

- Dilute samples to the range containing 0.1 $5 \mathrm{mg}$ glucose per ml.

- Prepare a buffer solution for the Glucose Analyzer by diluting a $5 \mathrm{~g}$ vial of YSI 2357 Buffer 7 G concentrate (Yellow Spring Co. Inc., Yellow Spring, Ohio) into $450 \pm 25 \mathrm{ml}$ distilled water.

- Inject sample or standard solution into the glucose analyzer using a YSI $2704 \quad 10 \quad 1$ syringepet (YSI Co., Inc. Yellow Spring, Ohio). The result will be read in units of $\mathrm{mg} / \mathrm{dl}$.

- Prior to reading, calibrate the glucose analyzer with a standard $500 \mathrm{mg} / \mathrm{dl}$ glucose solution (YSI Co. Inc., Yellow Spring, Ohio). 


\section{Alpha-Amylase Activity Determination.-}

CIpha-Amylase (1,4 - alpha-D-Glucanohydrolase) activity was determined using the method of Bernfeld (7) wherein the reducing groups liberated from starch are measured by the reduction of 3,5-dinitrosalycylic acid, One unit of enzyme activity was defined as the amount of micromole of maltose liberated per minute from soluble starch at $25{ }^{\circ} \mathrm{C}$ and $\mathrm{pH} 6.9$ under optimum conditions.

\section{Reagents:}

- $0.02 \mathrm{M}$ sodium phosphate buffer, pH 6.9 with 0.006 M sodium chloride.

- $2 \mathrm{~N}$ sodium hydroxide.

- Dinitrosalyclic acid color reagent. Prepare by dissolving $1.0 \mathrm{~g}$ of 3,5-dinitrosalycylic acid in $20 \mathrm{ml} 2 \mathrm{~N} \mathrm{NaOH}$. Add slowly $30 \mathrm{~g}$ sodium potassium tartrate tetrehydrate. Dilute to a final volume of $100 \mathrm{ml}$ with glass distilled water. Protect from carbon dioxide.

- 1\% Starch.- Prepare by dissolving $1.0 \mathrm{~g}$ soluble starch in $100 \mathrm{ml} 0.002 \mathrm{M}$ sodium phosphate buffer, pH 6.9 with $0.006 \mathrm{M}$ sodium chloride. Bring to a gentle boil to dissolve, cool and bring volume to $100 \mathrm{ml}$ with water if necessary. Incubate at $25{ }^{\circ} \mathrm{C}$ for $4-5$ minutes prior to assay. 
- Maltose stock solution, $5 \mathrm{micromoles} / \mathrm{ml}$. Prepare by dissolving $100 \mathrm{mg}$ maltose (M W 360.3) in $100 \mathrm{ml}$ glass distilled water. Incubate at $25^{\circ} \mathrm{C}$ for 4 - 5 minutes prior to assay.

\section{Procedure.-}

Using the maltose stock solution prepare a maltose standard curve by pouring into a series of numbered tubes $1 \mathrm{ml}$ of maltose dilutions ranging from 0.3 to 5 micromoles per ml. Include two blanks with distilled water only. Add $1 \mathrm{ml}$ of dinitrosalycylic acid color reagent. Incubate in a boiling water bath for 5 minutes and cool to room temperature. Add $10 \mathrm{ml}$ distilled water to each tube and mix well. Read in a Bausch \& Iomb Spectronic 21 Spectrophotometer (Bausch \& Lomb Co., Rochester, N.Y.) at 540 nm. Calculate the absorbance and fit to a straight line by the least square rule or plot absorbance versus micromoles maltose.

\section{Enzyme Assay.-}

1.0 - Pipette $0.5 \mathrm{ml}$ of sample solutions (or diluted samples into two series of numbered test tubes (include a blank with $0.5 \mathrm{ml}$ distilled water).

2.0 - Incubate tubes at $25{ }^{\circ} \mathrm{C}$ for $3-4$ minutes to achieve temperature equilibration. At timed intervals, add $0.5 \mathrm{ml}$ of starch solution at 
$25{ }^{\circ} \mathrm{C}$ to one series of test tubes and $0.5 \mathrm{ml}$ of distilled water to the other series to complete $1 \mathrm{ml}$.

3.0 - Incubate exactly 3 minutes and add $1 \mathrm{ml}$ dinitrosalycylic acid color reagent to each tube. 4.0 - Incubate tubes in a boiling water bath for 5 minutes. Cool to room temperature and add 10 ml glass distilled water. Mix well and read in a spectrophotometer at $540 \mathrm{~nm}$. Difference between two series of reading in maltose content will give alpha-amylase activity. (See Appendix A, Fig. A.3).

Beta-Amylase Activity Determination.

Beta-Amylase (1,4-Beta - D-Glucan maltohydrolase) was determined using the method of Bernfeld (8) wherein the rate at which maltose is liberated from starch is measured by its ability to reduce 3,5-dinitrosalycylic acid.One unit liberates one micromole of beta-maltose per minute at $25^{\circ} \mathrm{C}$ and $\mathrm{pH} 4.8$ under the specified conditions.

\section{Reagents:}

- 0.016 M Sodium acetate, pH 4.8

- 2 N Sodium hydroxide

- Dinitrosalycylic acid color reagent (the same as alpha-amylase) 
- 1\% Starch solution. Prepare by dissolving $1.0 \mathrm{~g}$ of soluble starch in $100 \mathrm{ml}$ of $0.016 \mathrm{M}$ sodium acetate buffer pH 4.8. Bring to a gentle boil to dissolve. Cool and, if necessary, dilute to $100 \mathrm{ml}$ with distilled water. Incubate at $25{ }^{\circ} \mathrm{C}$ for $4-5$ minutes prior to assay.

\section{Enzyme Assay.-}

- Follow the same steps as far the alpha-amylase determination using proper $1 \%$ starch solution. 


\section{IV.- RESULTS AND DISCUSSION}

\section{rged Fermentation of Pleurotus Ostreatus.-}

\section{ral Observations.}

This study was carried out using $1 \%$ potato waste flour as substrate, except when the effect of concentration on $P$. ostreatus growth was determined, and ammonium sulfate as the nitrogen source, except when the nitrogen source was to be studied.

The fermentation broth changed color from clear yellow to brown. This brown color may be attributed to enzymatic reaction rather than to the sugar-ammonia, sugaramine (Maillard browning) reactions. It is known that there are: ammonium ions in the solution due to ammonium sulfate addition, or amine radicals due to water soluble proteins of potato: or ammonium formation by $\underline{P}$. ostreatus, but the $\mathrm{pH}$ and temperature are very low to bring Maillard browning reaction. Color change was directly related to alpha-amylase activity, reducing sugar content and microorganism age.

The $\mathrm{pH}$ was observed to rise in value throughout each experiment from 5.5 (initial) to 6.8 or 7.2 in some cases. Rising $\mathrm{pH}$ was attributed to urea and ammonium formation 
by . ostreatus. This change in pH was not observed until the death phase in all the experiments. This agreed with studies done with mushrooms grown in solid state fermentation $(1,13,61,67)$ where pH change was directly related to mycelium maturity and the selected nitrogen source.

P. ostreatus produces specific extracellular enzymes according to the substrates. Production of alpha-amylase was observed in all of these experiments but beta-amylase was not detected. The amount of alpha-amylase varied experimental conditions.

When $\underline{P}$. ostreatus was grown on cellulosic materials it produced cellulase which hydrolize cellulose; when Iignin was used as substrate it produced laccase (63) and using starch as a substrate it produced alpha-amylase. Assays for cellulase and laccase were done on broth from fermentation of starch by $\underline{P}$. ostreatus but the results were negative. This means that some substrates have an inductive effect on enzyme production.

GIucose as Carbon Source.- When P. ostreatus was grown on $1 \%$ glucose solution as carbon source, at $27{ }^{\circ} \mathrm{C}$, $\mathrm{pH} 5.5$ (initial), using ammonium sulfate as nitrogen mource, $125 \mathrm{RPM}$, the lag phase was increased considerably compared to $1 \%$ of potato flour solution as carbon source and the other conditions remaining the same; the growth rate and yield of cell mass decreased relative to potato 
flour, as shown in Figure 6 . The maximum growth of the mi organism was reached after 16 days. Alpha-amylase was not present in the fermentation broth due to the repressive effect of glucose on enzyme production. The protein content determined by the modified Kjeldahl method, varied from $6.05 \%$ dry weight at 8 days to $37.75 \%$ dry weight at 16 days.

\section{of Substrate Concentration on Fungal Growth, Protein} Content and Enzyme Production.

This portion of the study was carried out using $1 \%$, $2 \%, 3 \%$, and $4 \%$ potato flour solution as substrate for $\underline{P}$. ostreatus ATCC 9415. The fermentation was carried out in a $250 \mathrm{ml}$ flask, at $27^{\circ} \mathrm{C}, \mathrm{pH} 5.5$, in an incubator shaker at 125 RPM.

Results obtained using $1 \%$ of the substrate are shown in Figure 7. Notice that the highest cell mass yield occurred at 14 days of fermentation. The crude protein content, dry content $\%$ in cell varied from $38.18 \%$ after 4 days to $48.75 \%$ after 14 days, decreasing during the death phase to $39.9 \%$ after 18 days. Protein content is reported as dry basis of eell mass. The net protein (protein determined by biuret method) varied from $35.97 \%$ after 4 days to $43.2 \%$ after 14 days. At the end of the process, after 18 days, the net protein content was $32.2 \%$. 
The highest value of alpha-amylase activity was observed after 4 days. Highest values of reducing sugar were obtained at day seventh (See Fig. 7). Alpha- amylase activity decreased after 4 days. This may be due to competitive inhibition by glucose which by that time reached $73.6 \%$ of the total reducing sugar content. Finally, the pH changed from 5.5 (initial) to 6.2 after 18 days of fermentation.

Results of fermentation using $2 \%$ of substrate concentration are shown in Figure 8. Maximum cell mass yield was at the eleventh day. Crude protein content varied from $39.9 \%$ to $47 \%$ and net protein content from $37.3 \%$ to $42.3 \%$.

Alpha-amylase activity and reducing sugar content reached their highest values after 5 days (See Fig. 8) and the $\mathrm{pH}$ value changed from 5.5 (initial) to 6.5 after 18 days of fermentation.

Figure 9 shows the highest yield of cell mass using 3\% substrate concentration and was obtained on the twelveth day while observed protein content changed in similar fashion to experiments $1 \%, 2 \%$, of substrate concentration.

Maximum alpha-amylase activity was observed on the fifth day and, for reducing sugar content, was on the Bixth day. The $\mathrm{pH}$ value changed from 5.5 (initial) to 6.4 after 18 days of fermentation.

Results obtained using $4 \%$ of substrate concentration are shown in Figure 10. 


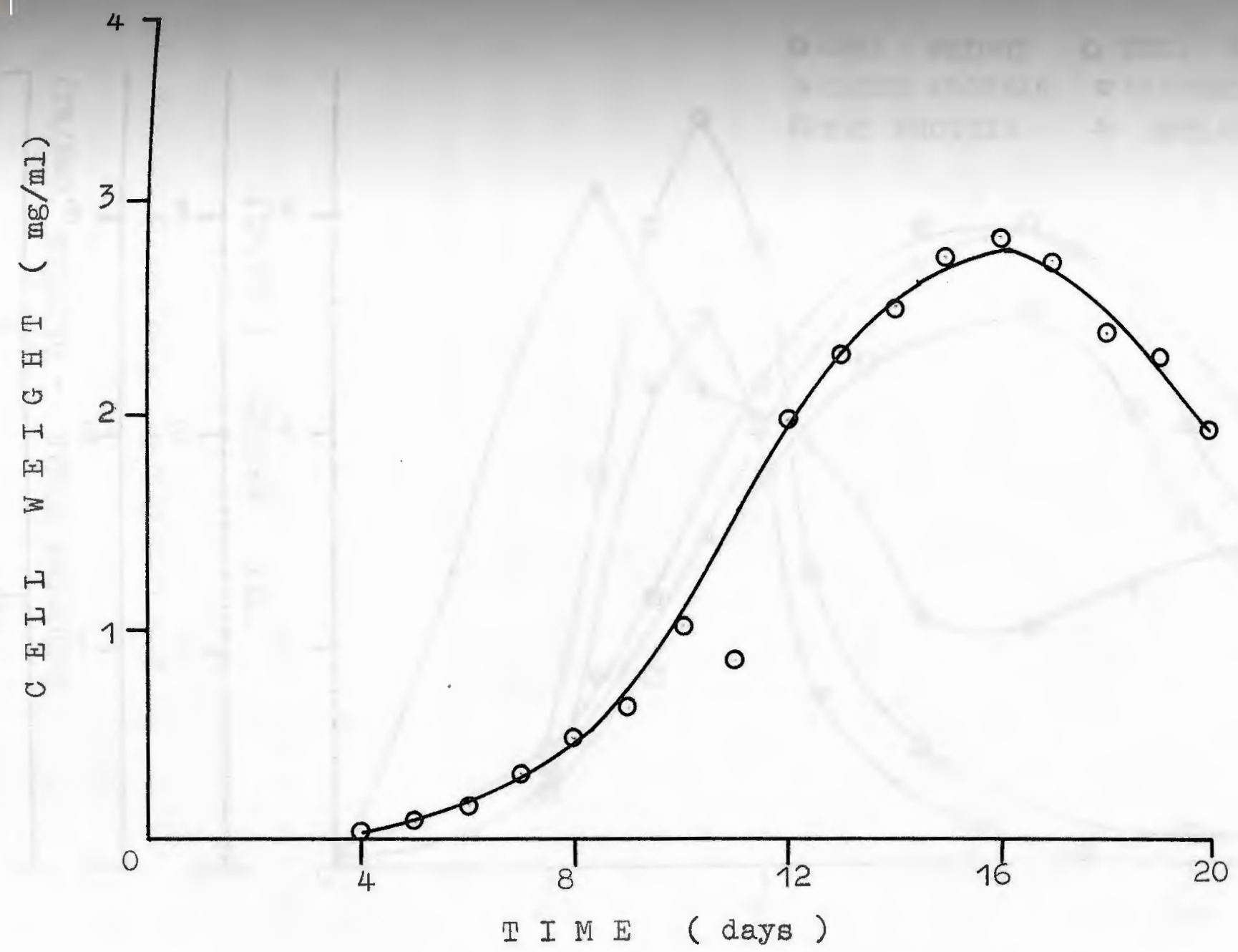

Fig. 6.- Growth of P. ostreatus on $1 \%$ glucose at $27^{\circ} \mathrm{C}, \mathrm{pH} 5.5$; ammonium sulfate was used as nitrogen source. 




T I M E ( d a $\mathrm{y} s)$

Fig. 7.- P. ostreatus growth on $1 \%$ substrate concentration, at $27^{\circ} \mathrm{C}$, pH 5.5, ammonium sulfate as nitrogen source. 
Notice that the highest cell mass yield occurred at 13 days of fermentation. Crude protein and net protein content varied in similar form to experiments $1 \%, 2 \%$, and $3 \%$ of substrate concentration.

The highest value of alpha-amylase activity was observed at 7 days and the highest value of reducing sugar content was obtained at 8 days of fermentation.

A summary of results using different substrate concentration is given in Table 5. Optimum substrate concentrations are $1 \%$ or $2 \%$ for cell mass yield, reducing sugar and alpha-amylase activity per gram of substrate; however, at $2 \%$ substrate concentration the cell mass doubling time is a minimum, and alpha-amylase activity is the highest at 5 days. High substrate concentrations seem to have a negative effect on $\underline{P}$. ostreatus growth and the fermentation products: cell mass, reducing sugar, and alpha-amylase activity. (See appendix. B, Figures B.1, B.2, and B.3).

When the substrate concentration was increased and the other nutrient concentration remained constant, cell mass also increased due to the increase in total level of nutrients and energy sources. However, yield results Indicate the efficiency of substrate utilization decreased. The likely explanations are: (1) a inhibition of microorganism growth at high glucose or reducing sugar concen- 


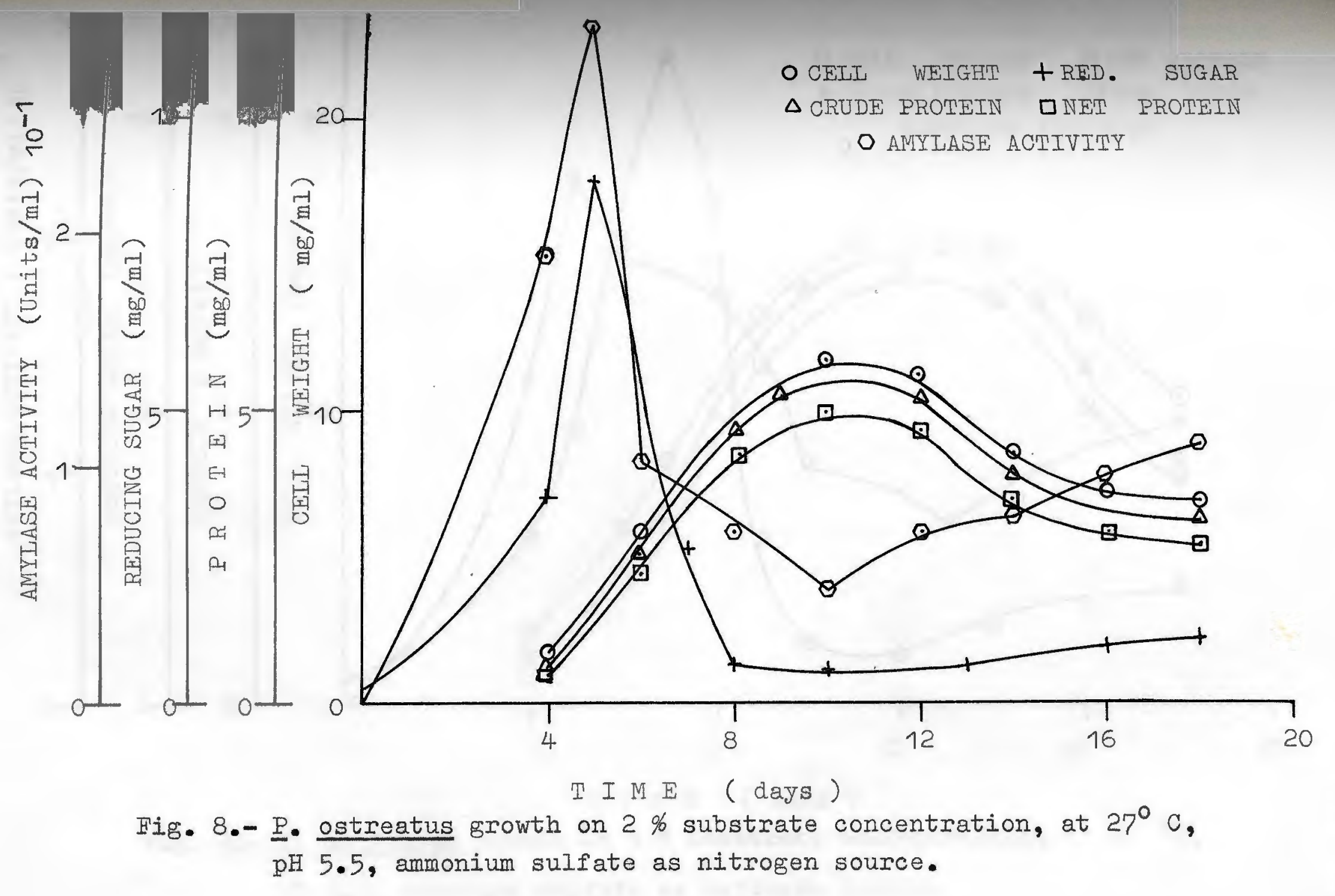




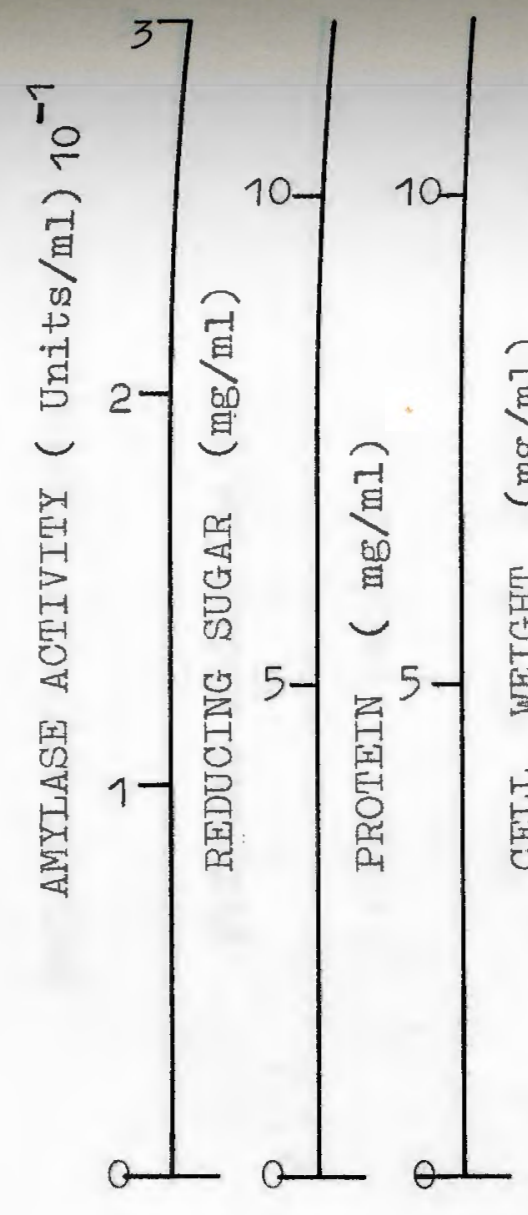

.



+AMYIASE ACTIVITY $\mathrm{pH}$ 5.5, ammonium sulfate as nitrogen source. 


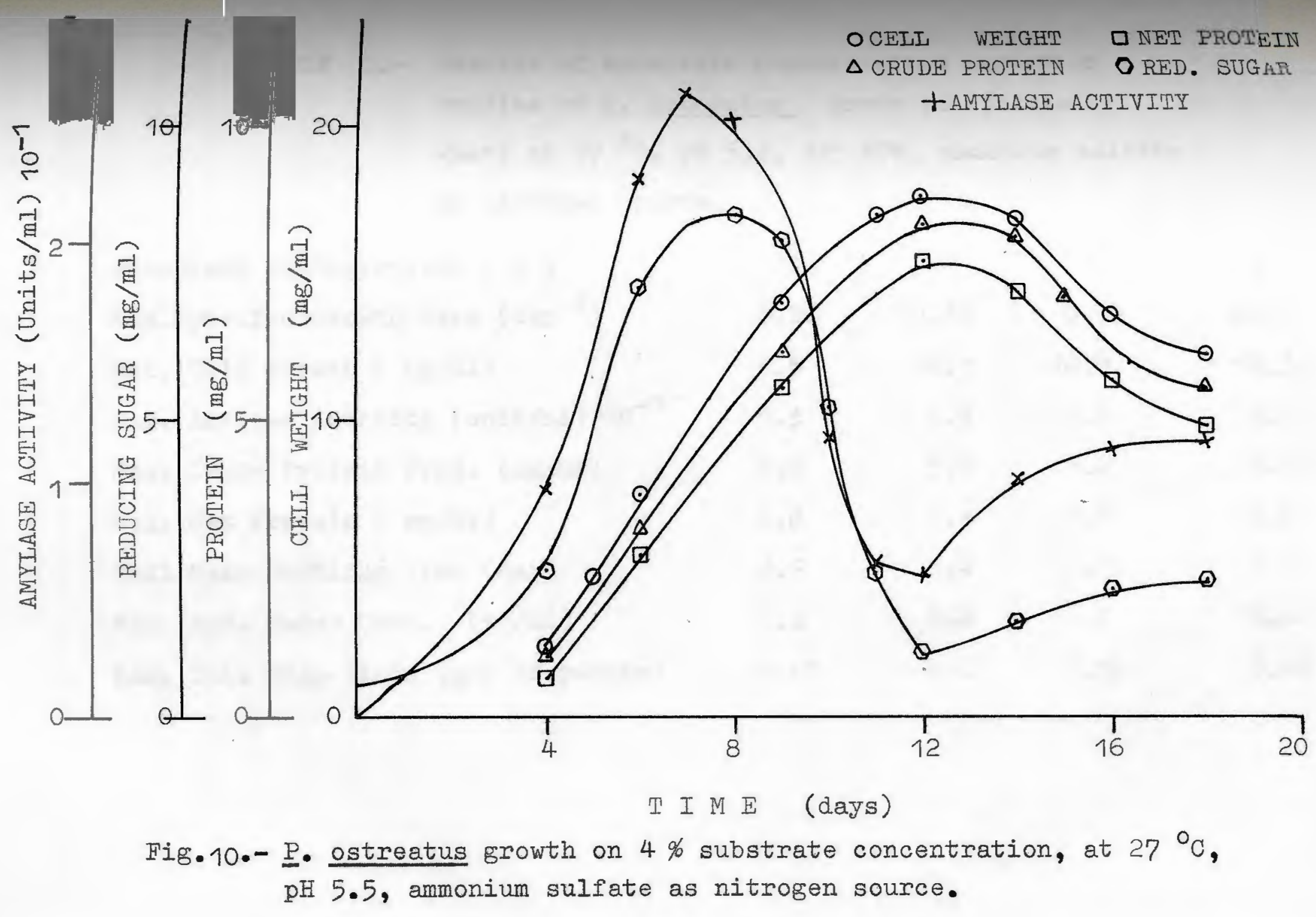




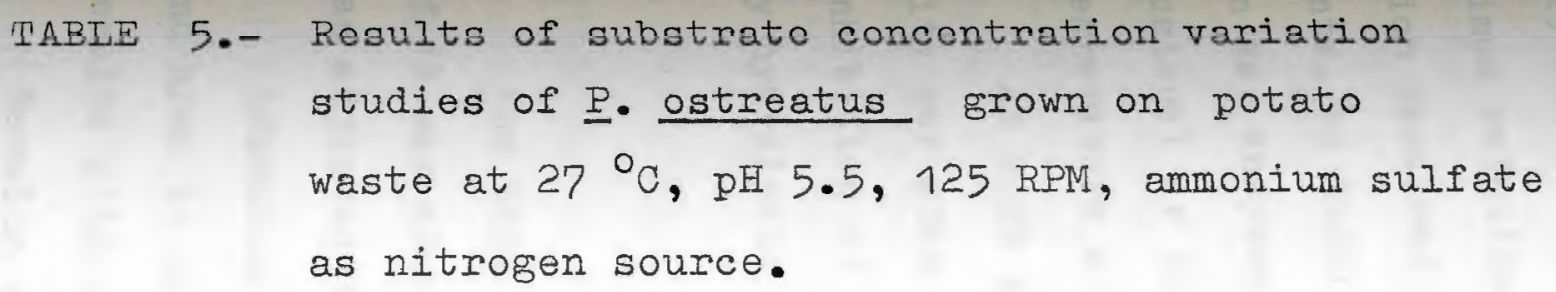

Substrate concentration ( $\%$ )

Max.Specific Growth Rate $\left(\right.$ day $\left.^{-1}\right)$

Max. Cell Growth ( $\mathrm{mg} / \mathrm{ml}$ )

Max. Amylase Activity (unit/ml) $10^{-1}$

Max. Crude Protein Prod. (mg/ml)

Max. Net Protein ( $\mathrm{mg} / \mathrm{ml})$

Cell Mass Doubling Time (day)

Max. Red. Sugar Conc. (mg/ml)

Max. Cell Mass Yield (g/g of potato)
1

0.26

6.5

1.3

3.2

2.8

2.7

3.5

0.61
2

0.37

12.1

2.9

5.7

5.1

1.9

9.0

0.60
3

0.33

16.9

2.2

8.2

7.4

2.1

11.3

0.56
4

0.27

18.5

2.7

8.5

7.6

2.5

8.4

0.46 
tration which may decrease water activity and consequently dehydration of cells in such concentrated solution. (2) The ratio nitrogen of carbon may not be at the optimum relationship since nitrogen source salt concentration remained constant. (3) Deficiency of any other nutrients, or toxic or inhibitory effects of specific compounds on key enzymes or structural cell components and; (4) Diffusional or kinetic limitations that will be seen with temperature effects on fungal growth.

At high substrate concentration alpha-amylase activity per gram of substrate decreased due to a competitive inhibition of glucose and other reducing sugars produced by hydrolysis of starch.

\section{Effect of Nitrogen Sources}

For this part of the study a potato concentration of $1 \%$ was always used at $27{ }^{\circ} \mathrm{C}, 125 \mathrm{RPM}$ and initial $\mathrm{pH}$ was adjusted to 5.5 with $0.1 \mathrm{~N} \mathrm{NaOH}$ or $0.1 \mathrm{~N} \mathrm{HCl}$.

Ammonium sulfate was compared with ammonium nitrate and urea to determine the effect of nitrogen source. Results with ammonium sulfate were shown in Figure 7.

Results with ammonium nitrate are shown in Figure 11. The highest cell mass yield per gram of substrate was obtained after 11 days. The best yield of reducing sugar was obtained after 8 days.

Results of $\underline{P}$. ostreatus growing with urea as nitrogen Bource are shown in Figure 12. 
The amount of ammonium nitrate and urea was in stoichiometric relationship to nitrogen contained in ammonium gulfate as proposed in the basic media, pg. 27. A comparison of cell mass yield using the different nitrogen pources is shown in Fig. 13 and Table 6 .

Ammonium sulfate as nitrogen source maximized cell mass yield compared to urea and ammonium nitrate. Results were similar to those in solid state fermentation of $\underline{P}$. ostreatus $(73,74)$ in that when ammonium nitrate was used, degradation of cellulosic materials and production of cell mass decreased with increasing ammonium nitrate levels. This phenomenon indicates a toxicologic effect of nitrates.

Sulfuric acid was added to ammonium nitrate and urea solutions in a stoichiometric relationship to provide the same amount of sulfate radicals as ammonium sulfate in the basic media. Results using ammonium. nitrate and sulfuric acid for $\underline{P}$. ostreatus growth are shown in Figure 14 and results using urea plus sulfuric acid are shown in Figure 15.

Sulfate ions have a positive effect on growth of P. ostreatus. A comparison of results are shown in Table 6 and Appendix B, Figures B.4, B.5, and B.6. When ammonium nitrate and sulfuric acid were used, the cell mass yield was higher than for ammonium sulfate alone or urea 
plus sulfuric acid (See Appendix B, Fig. B.4). For reacing sugar production and alpha-amylase activity, ammonium sulfate alone was the best nitrogen source. The growth rate with ammonium nitrate plus sulfuric acid is higher than that for ammonium sulfate or urea plus sulfuric acid.

The maximum reducing sugar production was obtained at 6 days using ammonium nitrate plus sulfuric acid, at 7 days using ammonium sulfate alone, and at 9 days using urea.

Alpha-amylase activity peak was observed at 4 days using ammonium sulfate alone, at 5 days using ammonium nitrate plus sulfuric acid, and at 6 days for urea plus mlfuric acid. The most suitable nitrogen source for reducing sugar production and alpha-amylase activity then was ammonium sulfate, and while ammonium nitrate with sulfuric acid is the most suitable for cell mass yield. The crude protein content of the dryed cell mass collected at the maximum level using ammonium sulfate as the nitrogen source was $50.27 \%$; with ammonium nitrate plus sulfuric acid it was $45.67 \%$, and with urea plus sulfuric acid was $50.01 \%$. This means ammonium sulfate is the most suitable and convenient nitrogen source to produce protein using potato as substrate for $\underline{P}$. ostreatus.

During the fermentation, the $\mathrm{pH}$ changed as follows: 1.0 - Ammonium sulfate: $\mathrm{pH}$ increased from 5.5 


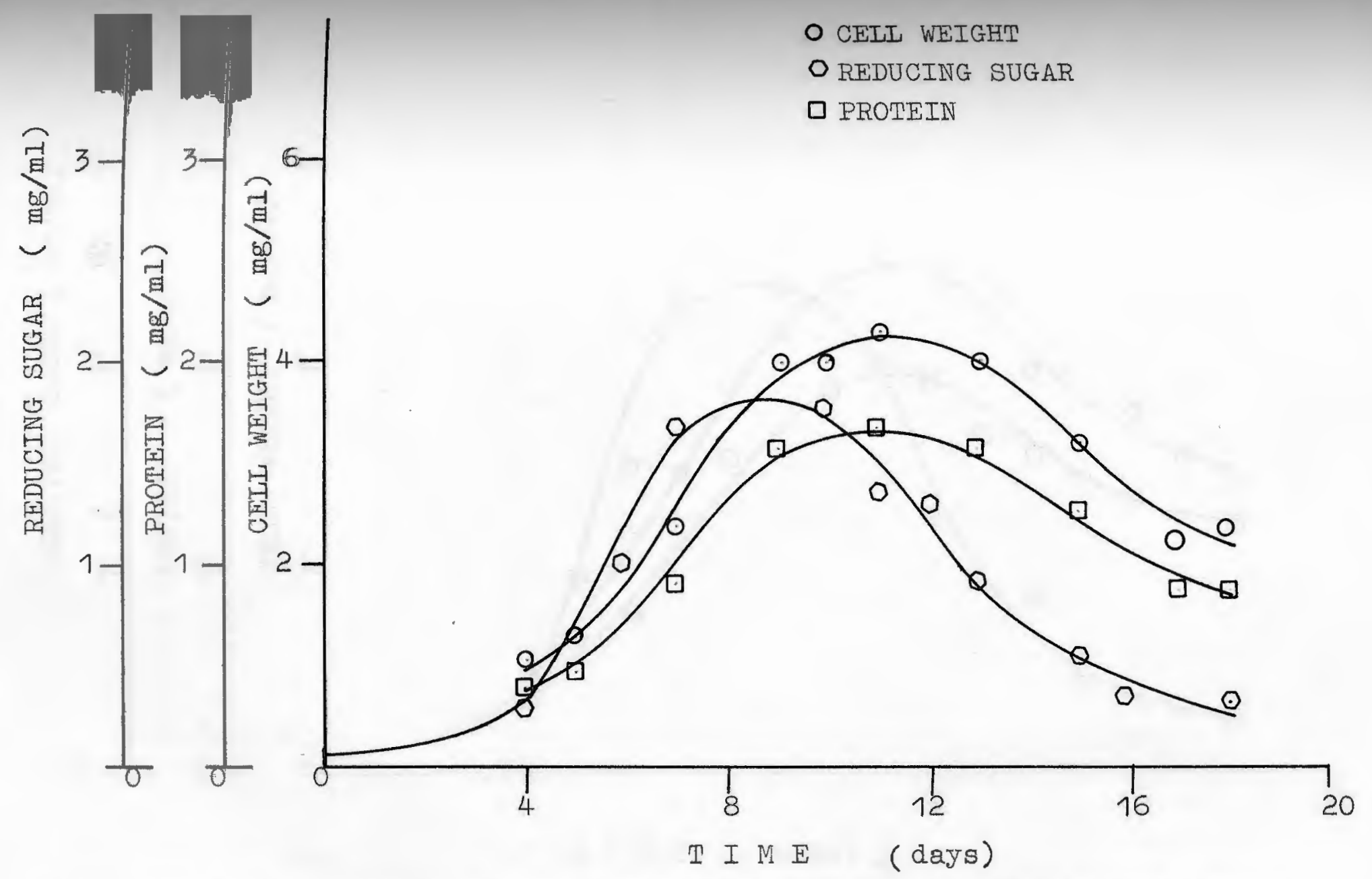

Fig. 11.- - ostreatus growth using ammonium nitrate as nitrogen source, at $27^{\circ} \mathrm{C}, \mathrm{pH} 5.5,1 \%$ substrate concentration. 


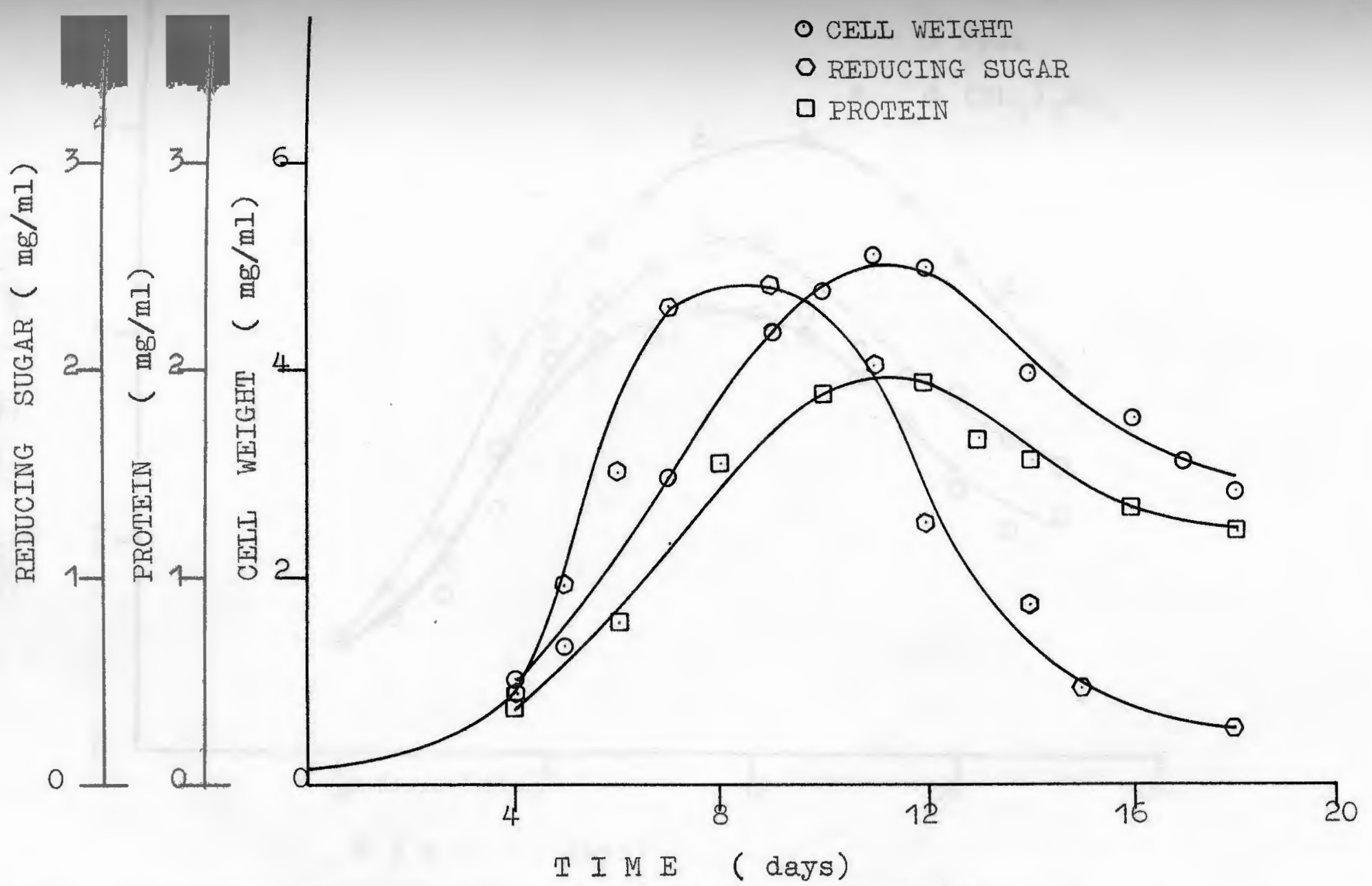

Fig. 12 - - . ostreatus growth using urea as nitrogen source, at $27{ }^{\circ} \mathrm{C}, \mathrm{pH} 5.5,1 \%$ substrate concentration. 


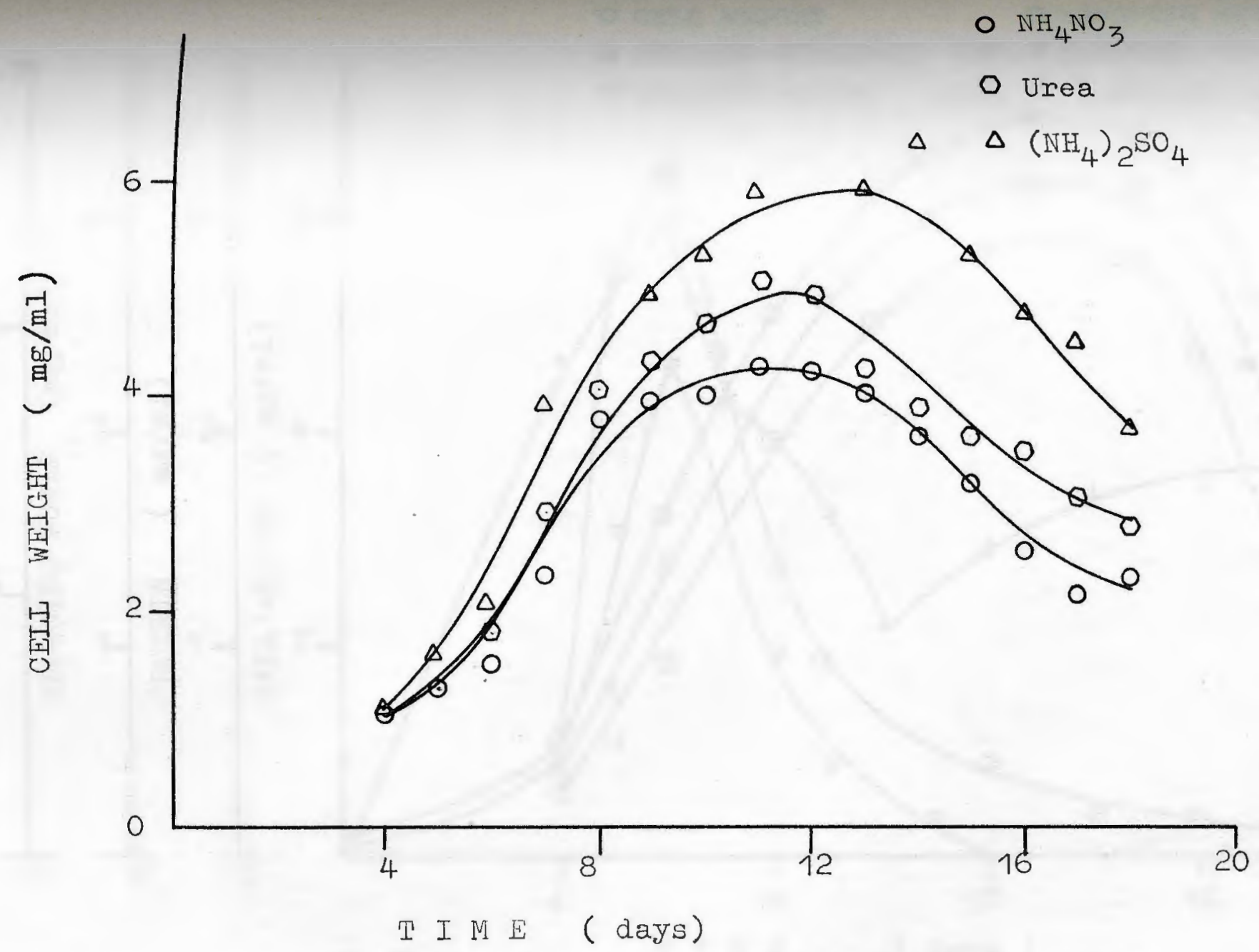

Fig. 13.- Comparison of cell weight obtained using different nitrogen sources. 




Fig. 14.- P. Ostreatus growth on $1 \%$ substrate concentration, at $27{ }^{\circ} \mathrm{C}$, pH 5.5, using ammonium nitrate plus sulfuric acid as nitrogen source. 


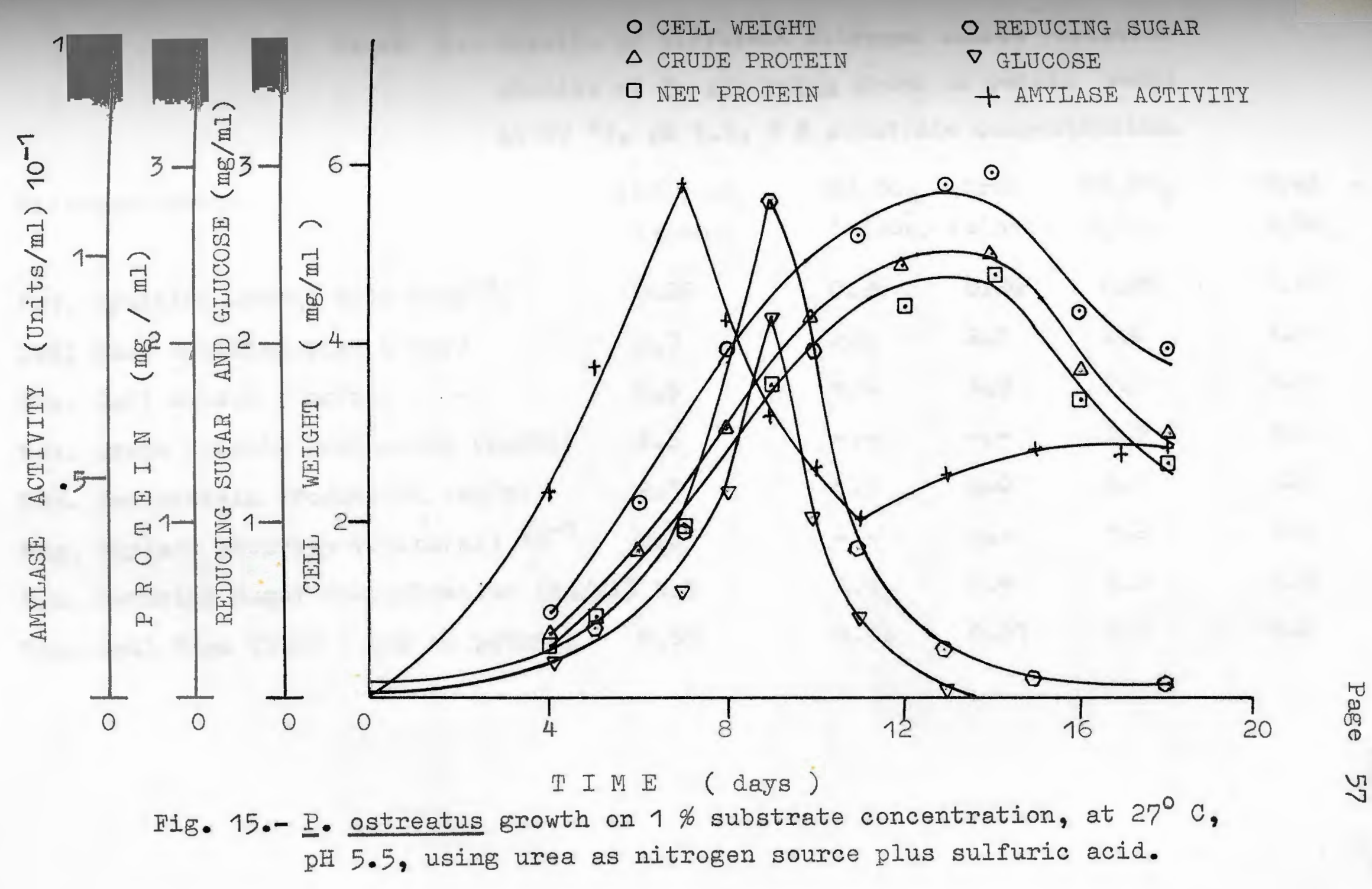


TABLE 6.- Results of different nitrogen source variation studies of $\underline{P}$. ostreatus grown on potato waste at $27{ }^{\circ} \mathrm{C}, \mathrm{pH} 5.5,1 \%$ substrate concentration.

\section{Nitrogen Source}

Max. Specific Growth Rate $\left(\mathrm{day}^{-1}\right)$

Cell Mass Doubling Time (day)

Max. Cell Growth ( $\mathrm{mg} / \mathrm{ml})$

Max. Crude Protein Production ( $\mathrm{mg} / \mathrm{ml}$ )

Max. Net Protein Production ( $\mathrm{mg} / \mathrm{ml}$ )

Max. Amylase Activity (Units/ml) $10^{-1} \quad 1.3$

Max. Redicing Sugar Concentration ( $\mathrm{mg} / \mathrm{ml}$ ) 3.5

Max. Cell Mass Yield ( $\mathrm{g} / \mathrm{g}$ of potato) 0.65

$$
\begin{gathered}
\left(\mathrm{NH}_{4}\right)_{2} \mathrm{SO}_{4} \\
\text { (alone) }
\end{gathered}
$$

0.26

2.7

6.5

3.2

2.5

$\begin{array}{llll}\mathrm{NH}_{4} \mathrm{NO}_{3} \\ \text { (alone) } & \begin{array}{l}\text { Urea } \\ \text { (alone) }\end{array} & \begin{array}{l}\mathrm{NH}_{4} \mathrm{NO}_{3} \\ \mathrm{H}_{2} \mathrm{SO}_{4}\end{array} & \begin{array}{l}\text { Urea } \\ \mathrm{H}_{2} \mathrm{SO}_{4}\end{array} \\ 0.26 & 0.26 & 0.26 & 0.24 \\ 2.6 & 2.6 & 2.6 & 2.9 \\ 4.4 & 5.0 & 7.3 & 5.9 \\ -.- & -.- & 3.3 & 3.0 \\ 1.6 & 2.0 & 3.0 & 2.8 \\ -.- & -.- & 1.2 & 1.2 \\ 1.9 & 2.4 & 3.2 & 2.9 \\ 0.43 & 0.51 & 0.7 & 0.6\end{array}$


to 6.2

2.0 - Urea: pH increased from 5.5 to 6.8 and, 3.0 - Ammonium nitrate: $\mathrm{pH}$ increased from 5.5 to 7.2

after 18 days of fermentation in all experiments.

\section{Effect of Temperature}

The effect of temperature on growth of $\underline{p}$. ostreatus was studied using a $1 \%$ potato substrate concentration, ammonium sulfate as nitrogen source, and shaker speed at $125 \mathrm{RPM}$. Results obtained at $20{ }^{\circ} \mathrm{C}, 27{ }^{\circ} \mathrm{C}$, and $30{ }^{\circ} \mathrm{C}$ are shown in Figures 16,7 , and 17 respectively.

P. ostreatus grows well at $20{ }^{\circ} \mathrm{C}, 27{ }^{\circ} \mathrm{C}$, and $30{ }^{\circ} \mathrm{C}$ in submerged culture, but at $20{ }^{\circ} \mathrm{C}$ and $30^{\circ} \mathrm{C}$ the growth rate is higher than at $27^{\circ} \mathrm{C}$. This does not agree with results obtained by Zadrazil (77) in solid state fermentation where the optimum temperatures. were reported be tween $15{ }^{\circ} \mathrm{C}$ to $20{ }^{\circ} \mathrm{C}$. Zadrazil, however does not report the particular strain used in his experiment.

Results for comparison are shown in Table 7 and Appendix B, Figures B.7, B.8, and B.9.

The maximum cell mass yield was observed after 13 days at $20{ }^{\circ} \mathrm{C}$, at $27{ }^{\circ} \mathrm{C}$ it was at 14 days and at $30{ }^{\circ} \mathrm{C}$ it was at 10 days. The highest cell mass yield per gram of substrate was at $27{ }^{\circ} \mathrm{C}$ and the protein content of the cell mass was in the same proportion for three cases. 
The maximum amount of reducing sugar was obtained after 9 days at $20^{\circ} \mathrm{C}$; and after 7 days at $27^{\circ} \mathrm{C}$ and $30^{\circ} \mathrm{C}$. The feducing sugar content was directly related to the amount of cell mass and it disappears as the microorganism grows.

Apha-anylase activity increased with increasing t-perature as seen in Appendix B, Fig. B.9. Not only was the maximum amount of alpha-amylase increased with hereasing temperature, but the rate of amylase produc$\ddagger$ tion was also increased.

To determine stoichiometric or kinetic limitation, menius equation has to be used as follows:

$$
\begin{aligned}
\mu & =\mathrm{A} \mathrm{e}^{-E a / R T} \\
\ln \mu & =\ln \mathrm{A}-\mathrm{Ea} / \mathrm{Rt}
\end{aligned}
$$

Moting $\ln \mu$ vs $1 / \mathbb{T}, \mathrm{Ea} / \mathrm{R}$ will be the slope of the fraight line, where:

$$
\begin{aligned}
& \mathrm{E} \mathrm{a}=\text { activation energy } \\
& \mathrm{R}=\text { gas constant }(1.987 \mathrm{cal} / \mathrm{g}-\mathrm{mole} \mathrm{K}) \\
& \mathrm{A}=\text { Arrhenius constant } \\
& \mu=\text { maximum specific grow rate. }
\end{aligned}
$$

With results obtained at different temperatures Ea was determined to be $-6.757 \mathrm{cal} / \mathrm{mole}$ which is very low for a chemical reaction, indicating a possible difMsional limitation in these experiments. 


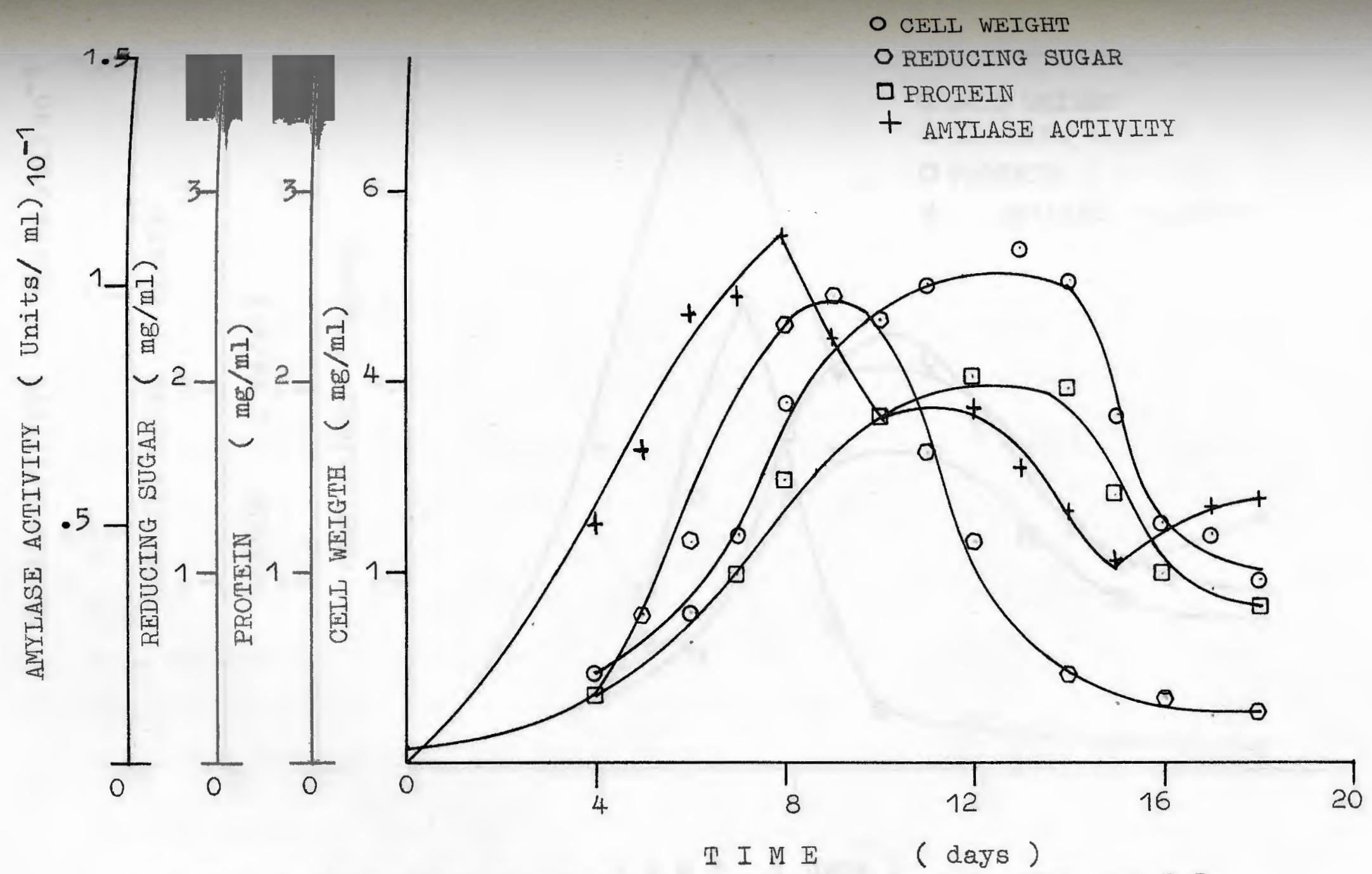

Fig.16.- - - ostreatus growth on $1 \%$ substrate concentration, pH 5.5, $20^{\circ} \mathrm{C}$, ammonium sulfate as nitrogen source. 


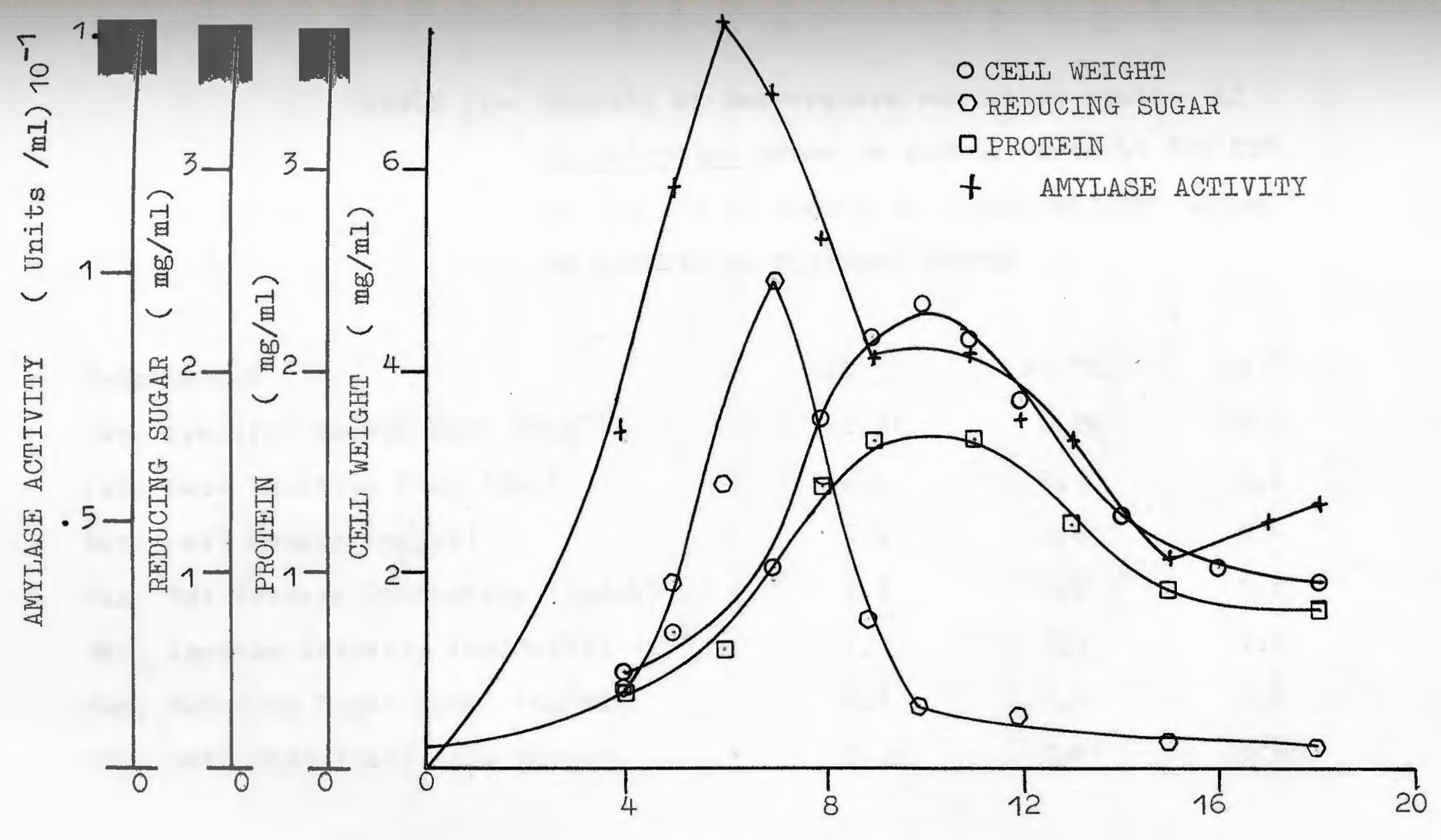

T I M E (days )

Fig. 17.- - - ostreatus growth on $1 \%$ substrate concentration, pH 5.5, at $30^{\circ} \mathrm{C}$, ammonium sulfate as nitrogen source. 
TABIE 7.- Results of temperature variation studies of

P. ostreatus grown on potato waste at 125 RPM, pH 5.5 and $1 \%$ substrate concentration; ammonium sulfate as nitrogen source

$\begin{array}{lccc}\text { Temperature } & 20{ }^{\circ} \mathrm{C} & 27{ }^{\circ} \mathrm{C} & 30{ }^{\circ} \mathrm{C} \\ \text { Max. Specific Growth Rate (day }{ }^{-1} \text { ) } & 0.31 & 0.26 & 0.30 \\ \text { Cell Mass Doubling Time (day) } & 2.2 & 2.7 & 2.3 \\ \text { Max. Cell Growth (mg/ml) } & 5.4 & 6.5 & 4.6 \\ \text { Max. Net Protein Production (mg/ml) } & 2.1 & 2.5 & 1.7 \\ \text { Max. Amylase Activity (Units/ml) 10-1 } & 1.1 & 1.3 & 1.5 \\ \text { Max. Reducing Sugar Conc. (mg/ml) } & 2.4 & 3.5 & 2.5 \\ \text { Max. Cell Mass Yield (g/g potato) } & 0.54 & 0.61 & 0.46\end{array}$




\section{Effect of Sodium Bisulfite $\left(\mathrm{NaHSO}_{3}\right)$}

This study was carried out using a $1 \%$ potato substrate solution, $\mathrm{pH} 5.5$, temperature at $27{ }^{\circ} \mathrm{C}$, shaker speed at 125 RPM, and ammonium sulfate as nitrogen source. It was found that in the presence of low concentrations of sodium bisulfite, $\underline{\text { P. }}$ ostreatus grew well but at increasing concentrations, the growth rate decreased considerably. Results at $50 \mathrm{ppm}, 100 \mathrm{ppm}$ and $150 \mathrm{ppm}$ of sodium bisulfite are shown in Figures 18, 19, and 20, respectively, and Table 8. Notice that when $\underline{P}$. ostreatus was grown in $50 \mathrm{ppm}$ of sodium bisulfite the growth rate is higher than in $100 \mathrm{ppm}$ and $150 \mathrm{ppm}$ (See Appendix B, Fig. B.10). Protein content in all of these experiments was in the same proportion, varying from $37 \%$ to $49 \%$ or $50 \%$ on dry cell mass basis.

However, there was a marked difference in alphaamylase activity and reducing sugar content. At $150 \mathrm{ppm}$ $\mathrm{NaHSO}_{3}$ the maximum amylase activity was 1.69 times less than that produced at $50 \mathrm{ppm} \mathrm{NaHSO}_{3}$ and 1.85 times less than that produced at $100 \mathrm{ppm} \mathrm{NaHSO}_{3}$.

Alpha-amylase activity was a maximum for this microorganism at 100 ppm sodium bisulfite. (See Appendix B, Fig. B. 12) 

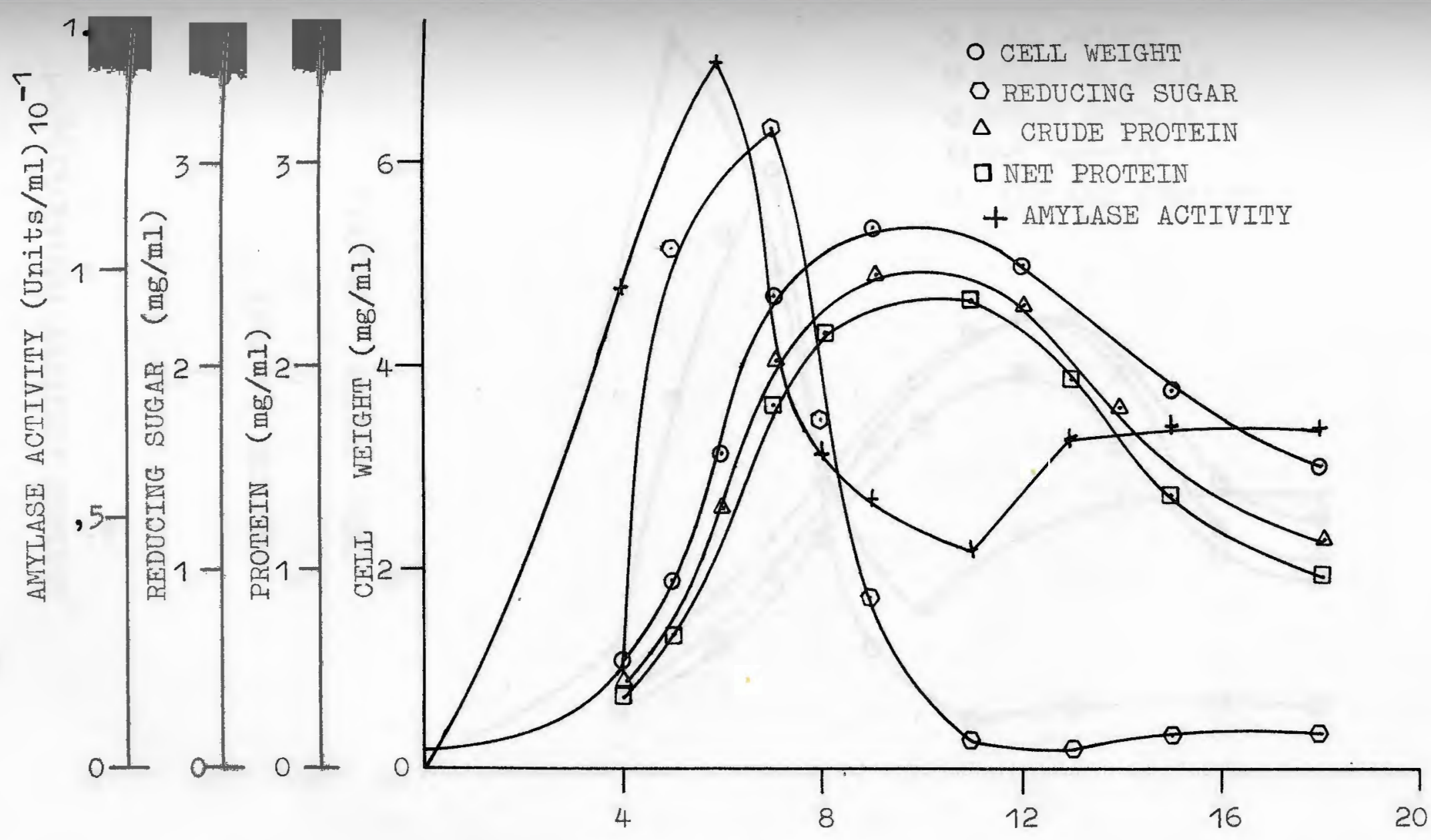

T I M E (days)

Fig. 18.- P. ostreatus growth on $1 \%$ substrate concentration, at $27^{\circ} \mathrm{C}, \mathrm{pH} 5.5$, $50 \mathrm{ppm}$ of sodium bisulfite and ammonium sulfate as nitrogen source. 




T I M E (days )

Fig. 19.- P. Ostreatus growth on $1 \%$ substrate concentration, at $27^{\circ} \mathrm{C}, \mathrm{pH} 5.5$, $100 \mathrm{ppm}$ of sodium bisulfite and ammonium sulfate as nitrogen source. 


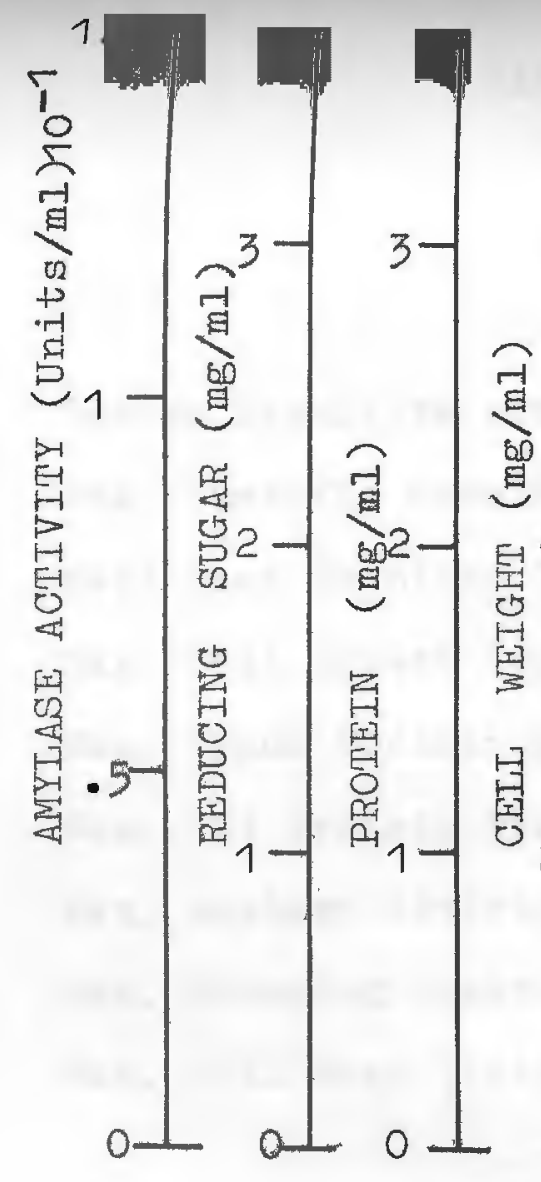

O CELI WEIGHT

O REDUCING SUGAR

$\triangle$ CRUDE PROTEIN

$\square$ NET PROTEIN

+ AMYLASE ACTIVITY

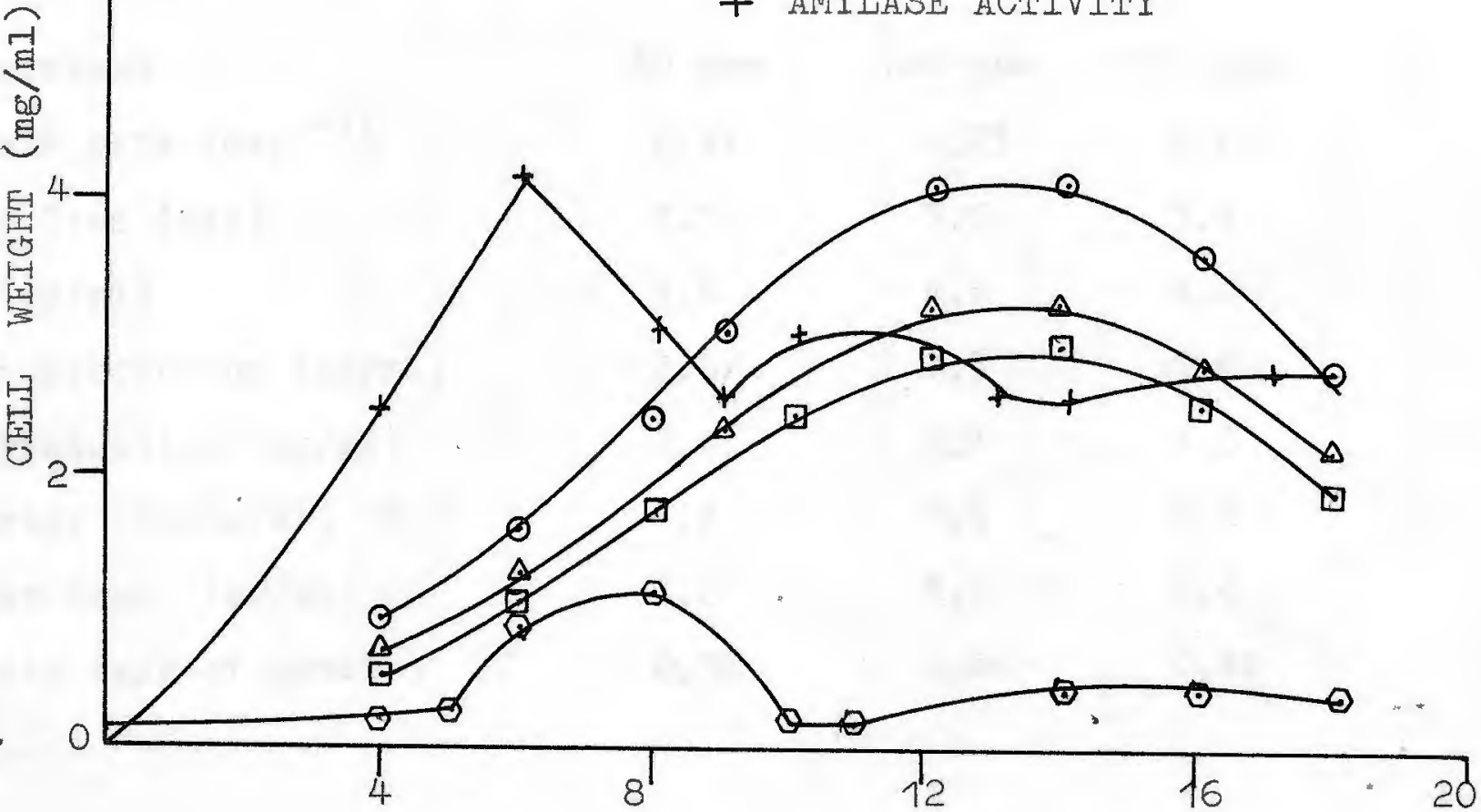

T I $\mathrm{N} E$ (days)

Fig. 20.- P. ostreatus growth on $1 \%$ substrate concentration, at $27^{\circ} \mathrm{C}, \mathrm{pH} 5.5$, $150 \mathrm{ppm}$ of sodium bisulfite and ammonium sulfate as nitrogen source. 
TABIE 8.- Results of $\mathrm{NaHSO}_{3}$ content variation studies of P. ostreatus grown on potato waste at $27^{\circ} \mathrm{C}$, $125 \mathrm{RPM}$ and 1\% substrate concentration

Sodium Bisulfite content

Max. Specific Growth rate $\left(\right.$ day $\left.{ }^{-1}\right)$

Ce11 Mass Doubling Time (day)

Max. Cell Growth $(\mathrm{mg} / \mathrm{ml})$

Max. Crude Protein Production ( $\mathrm{mg} / \mathrm{ml}$ )

Max. Net Protein Production ( $\mathrm{mg} / \mathrm{ml}$ )

Max. Amylase Activity (Units/ml) 10

Max. Reducing Sugar Conc. ( $\mathrm{mg} / \mathrm{ml}$ )

Max. Cell Mass Yield ( $\mathrm{g} / \mathrm{g}$ of potato)

$\begin{array}{ccc}50 \mathrm{ppm} & 100 \mathrm{ppm} & 150 \mathrm{ppm} \\ 0.41 & 0.23 & 0.20 \\ 1.7 & 3.0 & 3.4 \\ 5.6 & 4.6 & 4.2 \\ 2.9 & 2.3 & 1.6 \\ 2.6 & 2.1 & 1.5 \\ 1.4 & 1.5 & 0.8 \\ 3.2 & 3.1 & 0.6 \\ 0.56 & 0.46 & 0.42\end{array}$




\section{Effect of $\mathrm{pH}$ Variation}

The initial growth $\mathrm{pH}$ was changed from 4.5 to5.5, 6 or 8 . Results are shown in Figures $21,7,22,23$, respectively, and Table 9 . The highest cell mass yield was obtained at $\mathrm{pH} 6.0$ and the lowest at $\mathrm{pH}$ 8. Unfortunately, these set of experiments were initiated with a different innoculum from that used at $\mathrm{pH} 5.5$, therefore no comparison of these results can be made with $\mathrm{pH} 5.5$. Alpha-amylase activity was the highest at pH 4.5. Values obtained at $\mathrm{pH} 8$ are not shown in Figure B.15, Appendix B, because they were insignificant. Low $\mathrm{pH}$ had a positive effect on alpha-amylase activity but high $\mathrm{pH}$ had an inhibitory effect. Reducing sugar content is directly related to alpha-amylase activity, reaching its high values 1 day after alpha-amylase activity reached its high value.

\section{5-Liter Fermentor Study}

Two runs in a 5-liter fermentor were carried out at pptimum conditions determined in $250 \mathrm{ml}$ flask, $\mathrm{pH} 5.5$, $27{ }^{\circ} \mathrm{C}, 2 \%$ Substrate concentration, air flow rate 21 min. stirred at 150 RPM and ammonium sulfate as nitrogen source. In these experiments the microorganism grew in pellet form and floated on the broth surface, consequently, it was difficult to obtain homogeneous samples. 


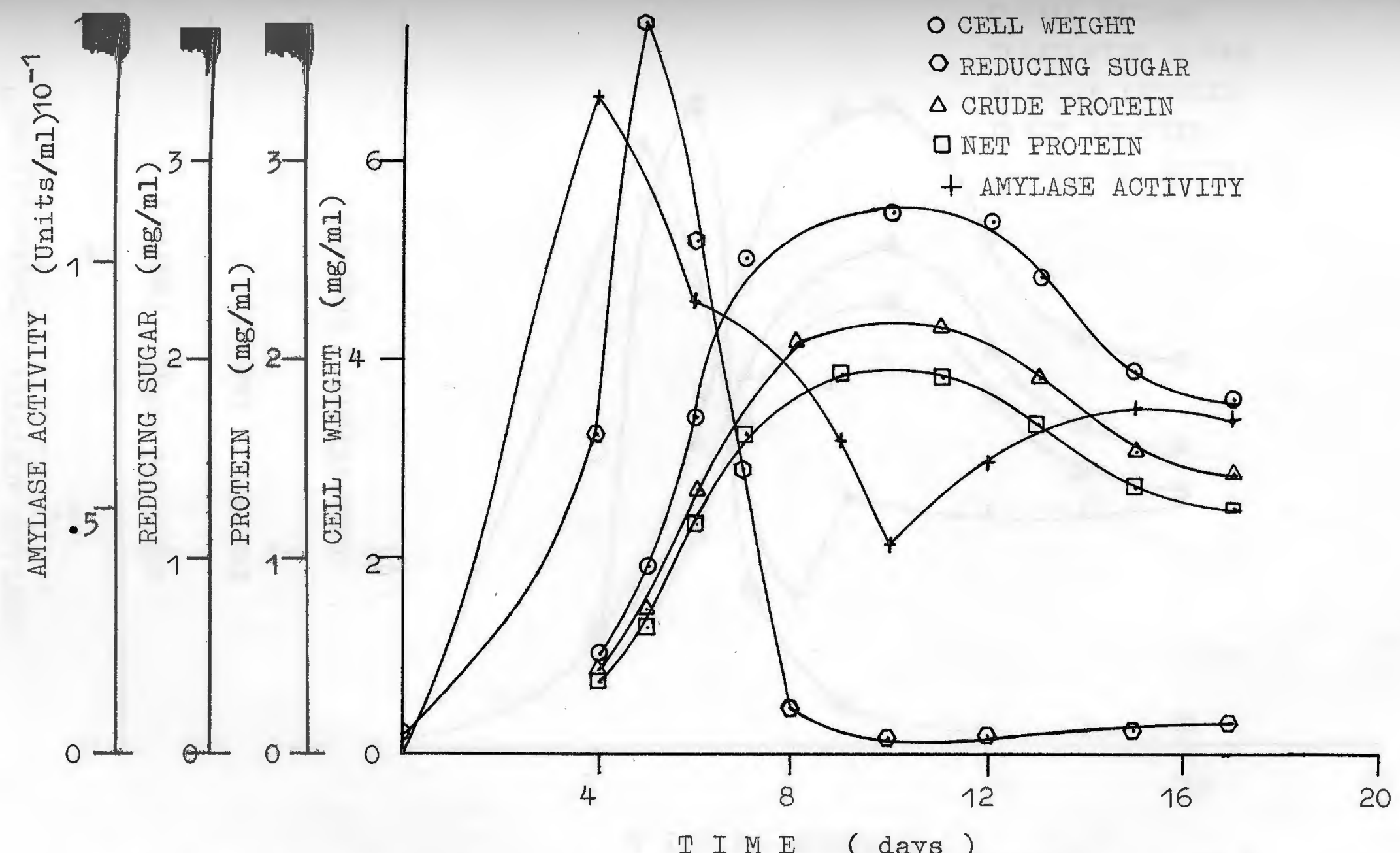

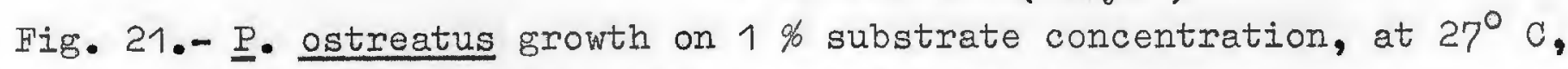
pH 4.5, ammonium sulfate as nitrogen source. 




T I M E (days)

Fig. 22.- - - ostreatus growth on $1 \%$ substrate concentration, at $27{ }^{\circ} \mathrm{C}$, pH 6 and ammonium sulfate as nitrogen source. 

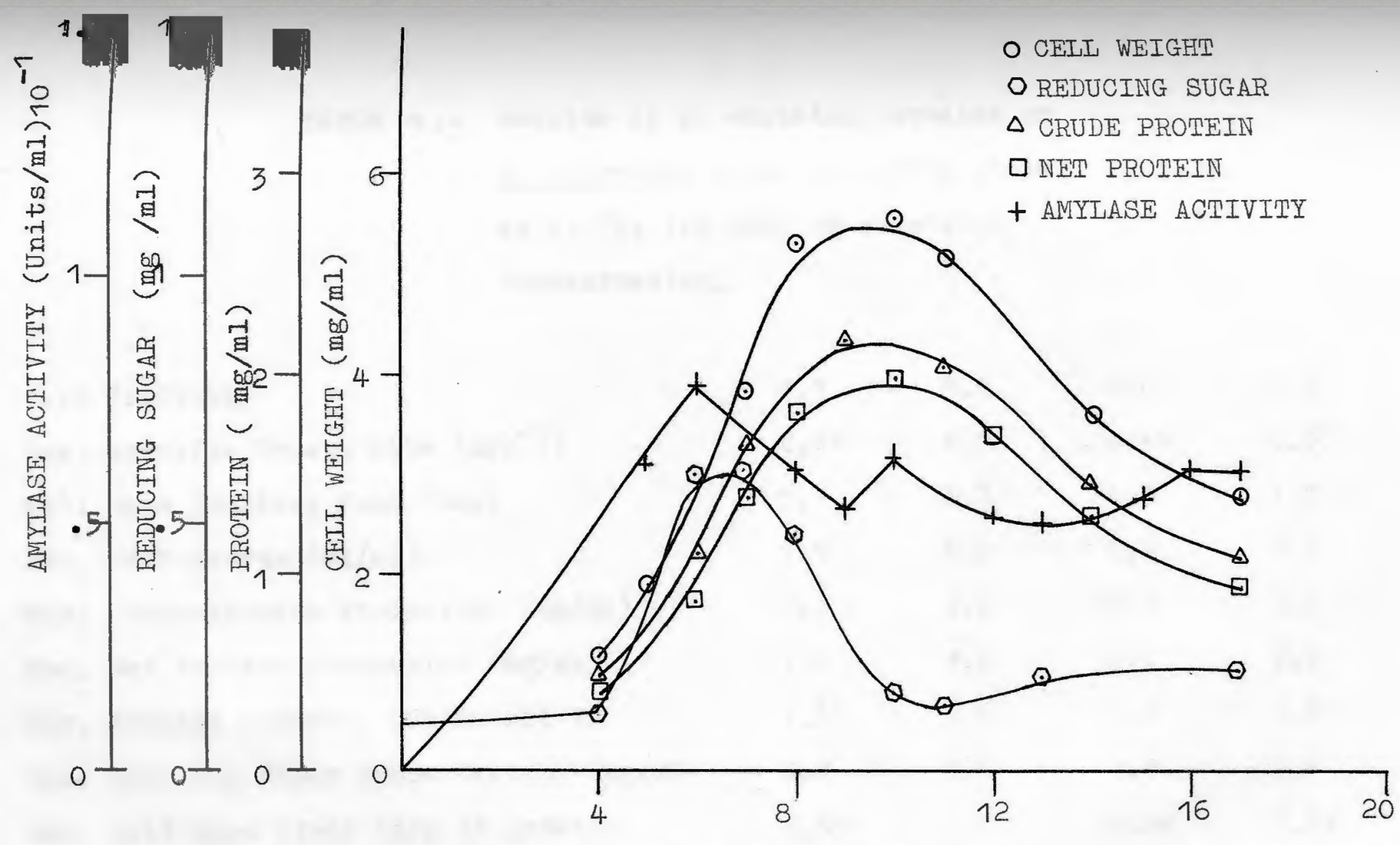

T I M E (days)

Fig. 23 - - - ostreatus growth on $1 \%$ substrate concentration, at $27^{\circ} \mathrm{C}$, $\mathrm{pH} 8$, ammonium sulfate as nitrogen source. 


\section{TABLE 9.- Results of $\mathrm{pH}$ variation studies of}

P. ostreatus grown on potato waste at $27{ }^{\circ} \mathrm{C}, 125 \mathrm{RPM}, 1 \%$ substrate concentration.

$$
\mathrm{pH} \text { (initial) }
$$

Max. specific Growth rate $\left(\mathrm{day}^{-1}\right)$

Cell Mass Doubling Time (day)

Max. Cell Growth (mg/ml)

Max. Crude Protein Production (mg/ml)

Max. Net Protein Production ( $\mathrm{mg} / \mathrm{ml}$ )

Max. Amylase Activity (Units/ml) 10

Max. Reducing Sugar Concentration (mg/ml)

Max. Cell Mass Yield ( $\mathrm{g} / \mathrm{g}$ of potato)
4.5

0.33

2.1

5.5

2.1

1.9

1.3

3.7

0.55
5.5

0.26

2.7

6.5

3.2

2.5

1.3

3.5

0.65
6.0

0.45

1.5

6.4

2.5

2.2

1.2

3.3

0.64
8.0

0.37

1.9

5.5

2.2

2.0

0.8

0.6

0.55 
TABLE 10.- 5-Liter Fermenter studies using 2\% substrate concentration, $\mathrm{pH} 5.5$, at $27{ }^{\circ} \mathrm{C}, 21 \mathrm{air} / \mathrm{min}$ and stirred at 150 RPM.

Time (days)

Cell Mass Yield (mg/ml)

Crude Protein Production (mg/ml)

Net Protein Production ( $\mathrm{mg} / \mathrm{ml}$ )

Amylase Activity (Units/ml) 10

Reducing sugar (mg/ml)

\section{4}

10.0

5.0

4.0

3.1

9.3
5

8.3

4.0

3.3

3.0

8.8 
The inoculum was prepared in a $300 \mathrm{ml}$ flask using $2 \%$ of substrate concentration at $\mathrm{pH} 5.5$ (initial) and $27{ }^{\circ} \mathrm{C}$. After four days, which is the lag phase period, it was transferred from a $250 \mathrm{ml}$ of inoculum to a 5-liter fermentor. It was observed that after two days the broth becomes completely clear and homogeneous. This suggests that the potato starch present in the broth was hydrolized. Broth color changed from clear yellow to brown but no $\mathrm{pH}$ changes were observed. A comparison of results for 4 days and 5 days of fermentation period is given on Table 10 . Results of the 5-liter fermentor studies compare well to shake flask results, based on cell mass yield. Using indirect inoculation, the lag phase was reduced suitablefor scale-up for continuous culture fermentation. 
Pages 76 and 77 are missing from the Santiago thesis. 


\section{Conclusions}

This study considered the feasibility of potato wastes as substrate for single cell protein and extracellular enzyme production by $\underline{P}$. ostreatus in submerged culture. conclusions of this study are the following:

1. $\cdots$ A two per cent substrate concentration maximized cell mass yield per gram of substrate, alpha-amylase activity and reducing sugar production in growing $\underline{P}$. ostreatus.

2. - P. ostreatus batch growth was carried out using three nitrogen sources: ammonium sulfate, ammonium nitrate, and urea. Cell mass yield, alpha-amylase activity and reducing sugar decreased with nitrogen source from a maximum using ammonium sulfate to a minimum using ammonium nitrate.

3.- When sulfuric acid was added to ammonium nitrate or urea, the cell mass yield and other products were improved.

4.- Cell mass yield was 1.12 times higher with mmonium nitrate plus sulfuric acid than with ammonium sulfate alone.

5.- The optimal temperature for $\underline{P}$. ostreatus growth at $1 \%$ substrate concentration was $27{ }^{\circ} \mathrm{C}$. 
6.- At $30{ }^{\circ} \mathrm{C}$, the production of alpha-amylase is 1.2 times higher than that at $27{ }^{\circ} \mathrm{C}$ using a $1 \%$ subtrate concentration.

7.- Optimal pH for cell mass yield was 5.5, but alpha-amylase and reducing sugar content were higher at $\mathrm{pH} 4.5$.

8.- P. ostreatus grows well at low concentrations of sodium bisulfite.

9.- Indirect inoculation reduces the lag phase. 10. - P. ostreatus under optimal conditions can achieve $0.6120 \mathrm{~g}$ of dry cell mass per gram of substrate. Protein content of this cell mass was $48 \%$ to $51 \%$ (reported as crude protein) or $43.2 \%$ (reported as net protein). 


\section{RECOMIMENDATIONS}

1.- Study the effect of the different variables on nucleic acid contained in $P$. ostreatus grown in submerged culture using potato wastes as a substrate.

2. - Study if mycotoxins or other toxin forms are produced growing $\underline{P}$. ostreatus on submerged fermentation to be used directly as human food, since $\underline{P}$. ostreatus grown in solid state fermentation does not contain toxins.

3.- Study the kinetics and stability of alpha-amylase produced by $P$. ostreatus which can justify this microprganism as a source of starch hydrolizing enzymes. 
1.- Aalto, A., and Kreula, M. (1972) Eraiden metsasienten aminohappo-ja rasvahappokoostumukseta. Karjantute, 55, $264-265$.

2.- Ander, P. and K.E. Erickson (1976) The importance of phenol oxidase activity in lignin degradation by the white-rot fungus Sporotrichum pulverulentum, Arch. Microbiol. 109, 1 - 8.

3.- Artschwager, e., Studies on the Potato Tuber., J. Agr. Research 27, 809 - 835.

4.- Aylward, Francis and Jul, Mogens: Protein and Nutrition Policy in Low-Income Countries., John Wiley and sons, N.Y., 1975, p. vi.

5.- Bano, Z. and Srivastava, H.C., Studies on Cultivation of $\underline{P}$. ostreatus on Paddy Straw. Food Sci. 12 $363-5,1962$.

6. Bergmeyer, H., and Bert, E., in Bergmeyer H. editor "Methods of Enzymatic Analysis". vol 3, 1205, Weinheim: Verlag Chemie. N.Y. Academic Press (1974). 
7.- Bernfeld, P., Enzymes of Starch Degradation and Synthesis in "Adxances in Enzymology"., vol. XII Nord, F.F. ed., 379, Interscience Publishers, N.Y. 1951. 8.- Bernfeld, P. Amylases, Alpha and beta in Methods in Enzymology., vol. I, (Colowick, S. P., and Kaplan, N.O. eds.) p. 149, Academic Press, N.Y. (1955).

9.- Bhattacharjee, J. K., Microorganisms as a Potential Source of Foods, Advances in Applied Microbiology, 13: 139 (1970).

10.- Cochrane, W. W., The World Food Problem, T.Y. Crowel1, New York, (1969).

11.- Cooper, Terrance G. The Tools of Biochemistry, John Wiley \& Son, New York, 1977, p. 36 - 80.

12.- Cowling, E. B., and Merrill, W., Distribution and reuse of Nitrogen in Wood Destroying Fungi. Holzu. Orgamismen, Beiheft 1, 269 - 274, (1966).

13.- Dijkstra, F. Y. (1976) Studies on Mushroom Flavours 3, Some Flavor Compounds in Fresh, Canned and Dried Edible Mushrooms. Z. Lebensm. Unters- Forsch, 160, 401.

14.- Dijkstra, F., Submerged Cultures of Mushroom Mycelium as Sources of Protein and Flavor Compounds, Drukkerij, J. H. Pasmans, S-Gravenhage, Delft, 1976. 15.- Dunlap, C.E. Protein from Waste Cellulose by Chemical-Microbial Processing, Ph. D. Thesis, Louisiana State University (1969). 
Page 83

16.- Eger, G., Gottwald, H. D., and Von Netzer, U. (1974) The Action of Iight and other Factors on Sporophore Initiation in Pleurotus ostreatus. Mushroom Sci. 9 $575-583$.

17.- Eger, G., Biology and Breeding of Pleurotus., in "The Biology and Cultivation of Edible Mushrooms", (S.T. Chang and W. A. Hayes, eds.) p. 497, Academic Press, (1978).

18.- Falk, R., Uber die Waldkultur des Austernpilzes (Agaricus Ostreatus). Eine Anweisung zur Pilkultur aut frischen Iaubholzstubben Z. Pilzkd. 3, 102 - 106, 1919.

19.- Faust, U. Prave, P. "Process Alternatives in SCPFermentation"., Process Biochemistry, vol., 14, \#11, 1979.

20.- Food and Agricultural Organization, World Food Problems N으 4, 6 Billion to Feed, Food and Agricultural Organization (FAO) of the United Nations, Rome, 1962.

21.- Food and Agricultural Organization, Agricultural Commodity Projection 1970 - 1980, vol. 1, Food and Agricultural Organization of the United Nations, Rome, 1971.

22.- Ginterova and Maxianova, A., The Balance of Nitrogen and Composition of Proteins in P. ostreatus grown on Natural Substrates; Folia Microbiol. Prague, 20, 
$246-250,1975$.

23.- Ginterova, A., Nitrogen Utilization of Certain Strains of Ascomycetes and Basidiomycetes in submerged and Stationary Cultures. Mykol. Sb. 8, 60 - 63, 1971. 24.- Ginterova, A., Nitrogen Fixations by Higher Fungi, Biologia (Bratislava) 28, 199 - 202, 1973.

25.- Gray, W. D., The use of Fungi as Food and in Food Processing, The Chemical Rubber Co. Cleveland, Ohio $1970,40-41,121-122,134,166,202$.

26.- Herzig, I., Dvorak, M., and Veznik, Z., Treatment of litter straw by application of the fungus P. ostreatus., Fr. Biol. Chem. Vyz Hospadarskych Zvirat 3, $249-253,1968$.

27.- Hofsten, B.V., and Ryden, A. I., Biotech. Bioeng. $17,1183-1197,1975$.

28.- Humphrey, A.E., Moreira, A., Armiger, W., and Zabri= skie, D., "Production of Single Cell Protein from Cellulosic Waste" in "Single Cell Protein from Renewable and Nonrenewable Resources" (E.I. Gaden, Jr. and A.E. Humphrey, eds.), Biotech. Bioeng. Symposium Series, No. 7, p. 45. (1977).

29.- Humphrey, Arthur E., in "Single Cell Protein" II (R.I. Mateles and S. R. Tannenbaum, eds.), M I T Press, Cambridge, Mass. p. 3, (1975).

30.- Kalberer, P., The Cultivation of Pleurotus ostreatus Experiments to Elucidate the Influence of Different 
Culture Conditions on the Crop Yield. Mushroom Sci. IX, $653-661$. (1974).

31.- Kalberer, P., and Kunsch, U., (1974). Amino Acid Composition of the Oyster Mushroom (P. ostreatus) Lebensm. Wiss. U. Technol. 7, $242-244$.

32.- Kapsiolis, P. G., Sources Potentielles Comestibles., Industr. Alim. Agr. 1157 - 1168 (1968).

33.- Kihlberg, R., The Microbe as a Source of Food, Annual Review Microbiology; (1972), 26: 427.

34.- Klingman, A. M., "Handbook of Mushroom Culture" 2nd Ed., T. B. Swayne, Kennett Square, PA. 1950.

35.- Krieger, I.C. C. "The Mushroom Handbook", Dover Publications, Inc. New York, 1967.

36.- Kroner, W., and Volksen, W., The Potato, 2nd. Edition Johann Ambrosius Barth, Leipzig.

37.- Kubitscheck, H. E. Introduction to Research with Continuous Cultures, Englewood Cliffs, N.J. Prentice Hall, 1970.

38.- Kurtzman, Ralph H., Jr. "Mushrooms: Single Cell Protein from Cellulose", Annual Report on Fermentation Process, 3, $305-339,1979$.

39.- Kurtzman, Ralph H., Jr. The Metabolism of Fatty Substances by the Oyster Mushroom., Mushroom Sci. IX, 557 - 565, 1974.

40.- Kurtzman, Ralph H., Jr. "Solid State Fermentation of Lignin by $\underline{P}$. ostreatus", paper presented at the 
Annual Meeting of American Chemistry Society, San Francisco, Cälifornia (1976).

41.- Kurtzman, Ralph H., Jr. Mushroom as a Source of Food Protein in Protein Nutritional Quality of Foods and Feeds, Part 2, (M. Friedman, ed.), p. 305 , Narcel Decker, 1975.

42.- Iampitt, I., And Goldenberg, N., The Composition of the Potato, Chem, and Ind. 18, 748 - 761, 1940. 43.- Iin, K, C., "The Microbe as a Source of Food or Feed", Food Industry, 7, 8, Taiwan R. O. C. 1976. 44.- Linne, C., and Martens, R., Z. Pflanzenern. Bodenk. 141,265 (1978).

45.- Iuthard, W., Holzbewohnende Pilz-Anzuchtund Holzmykologie, Wittenberg: Ziemsen - Verlag, 1069.

46.- Mac Lennan, D. G., "Single Cell Protein from Starch a New Concept in Protein Production", Food Technol. in Australia, April (1975) p. 141 - 147.

47.- Mandels, M., Hontz, I., and Nystrom, J., Biotech. Bioeng., 16, 1471 - 93, 1974.

48. - Mateles, R. I., and Tannenbaum, S. R., eds. "Single Cell Protein", The MIT Press, Cambridge, Mass, 1968. 49.- Mandelstam, J. and K. Mc. Quillen, Biochemistry of Bacterial Growth, 2nd Ed. N.Y. John Wiley \& Sons 1973.

50.- Miller, G.I., Analytical Chem. 3 (13), 426 - 428, 1959. 
51.- Mother Earth News, No. 59, Sep/Oct. p. 66 - 68, 1979. 52.- Nystrom, J. M., and S. M. Barnett, eds. "Biochemical Engineering: Renewable Sources of Energy and Chemical Feedstocks", AIChE Symposium Series No. 181, American Institute of Chemical Engineers, N.Y. 1978. 53.- Orten, James M., Neuhaus, Otto W., Biochemistry, The C. V. Mosby Company, St. Louis, (1970) p. 167170 .

54.- Paca, J. "Bioengineering Aspects of Aerobic Microbial Piggery Waste Treatment", European Journal of Applied Microbiology and Biotechnology. Vol. 8, No. $\frac{1}{2}, 1979$.

55.- Passecker, F., Kulturversuche mit Wildformen des Champignons und anderen Agaricaceen, Mushroom Sci. 477 - 483, 1959.

56.- Patton, J. T., Jurgensen, M. F., and Delaney, B. J. Process Biochem. vol 14, No. 6, 1979.

57.- Protein Advisory Group of the United Nations System, PAG Bulletin, 2 (1), 2 (1972).

58. - Ra jathnam, S., Wankhede, D. B., and Patwardhan, M. V., Some Chemical and Biochemical Change in Straw Constituents During Growth of P. Flabellatus, European Journal of Applied Microbiology and Biotechnology, vol. 8, No. $\frac{1}{2}$, p. 125, 1979.

59.- Rangaswami, G., Kandaswami, T., Ramasamy, K., Pleurotus sajor-caju (Fr) Singer, a Protein rich Nitro- 
Fixing Mushroom Fungus, Curr. Sci. 44, 403-404, 1975. 60.- Schisler, I.C., and Patton, T. G., Jr. Mushroom Sci. 9, (1) 175, 1976.

61.- Schormuller, J. (1974) Lehrbuch der Lebensmittelchemie, 2, vollstandig neubearbeitete Auflage, BerIin Heidelberg, New York, Springer - Verlag, 522. 62.- Scrimshaw, N., in Single Cell Protein ( R. I. Mateles and S. R. Tannenbaum, eds.) MIT Press, Cambridge, Mass. 1968, p. 3.

63.- Sheih, C. S., S. M. Barnett and A. U. Hira, Production of Enzymes and Single Cell Protein from Rice Hulls in Food Processing, vol II, Edited by P. Linko, et, al. Applied Science Publishers, Essex, England 1980.

64.- Sinden, J.W., Mushroom J. (ㅁ) 268, 1973.

65.- Singer, R., The Agaricales in Modern Taxonomy, 3rd ed. J. Cramer, Vaduz, 1975.

66.- Snyder, H.E., Advan. Food. Res., 18, 85 (1970).

67.- Stein von Kamienski, E., (1958), Untersuchungen uber die fluchtigen Amine der Pflanzen, III, Die Amine von Pilzen. Ueber den Weg der Aminbildung in Pflanzen. Planta, 50, 331 - 52 .

68.- Umbreit, W.W. Advances in Applied Microbiology, vol. 5, Academic Press Inc. N.Y. 1963.

69.- Waslien, C. I., Calloway, D. H., Margen S. and Costa, F., Journal Food Sci. 35, 294 (1970). 
70. - Watt, B.K. and Merrill, A, I. Composition of Foodsraw, processed, prepared. U.S. Dept. Agr. Handbook No. 8 Revised 1963.

71.- West, Edward S. Textbook of Biochemistry, The McmilIan Co. New York, 1961, p. 242. 262.

72. - Worthington, "Enzymes, enzyme reagents and related Biochemicals!, Ed. Lillian A. Decker, New Jersey, 1977, p. $173-179$.

73.- Zadrazil, F., "Influence of Ammonium Nitrate and Organic Supplements on the Yield of Pleurotus sajorcaju European Journal of Applied Microbiology and Biotechnology, vol 9, No. 1, 1980, p. 31.

74.- Zadrazil, F., and H. Bunnert, The influence of Ammonium Nitrate Supplementation on Degradation and in Vitro Digestibility of Straw Colonized by Higher Fungi, European Journal of Applied Microbiology and Biotechnology. Vol 9, No. 1, 1980, p. 37.

75. - Zadrazil, F., the conversion of straw into feed by Basidiomycetes. Eur. J. Appl. Microbiol. 4, 273, $281,1977$.

76.- Zadrazil, F., Die Zersetzung des Stroh-ZelluloseLignin-Komplex mit Pleurotus species und dessen Nutzung Z. Pflanzenernahr. Bodenkd. 138, $263-278$, 1975.

77.- Zadrazil, F., Cultivation of Pleurotus in The Biology and Cultivation of Edible Mushrooms, edited by 
S. T. Chang and W. A. Hayes, Academic Press, New York, 1978, 521 - 557. 78.- Zadrazil, F., The Ecology and Industrial Production of Pleurotus ostreatus, Pleurotus florida, Pleurotus cornucopiae and Pleurotus eryngii. Mushroom Sci. IX, 621 - 652., 1974. 
A P P E N D I X A 




STANDARD FOR PROTEIN DETERMINATION: Biuret Method. 
Page 93

APPENDIX A

FIG. A.2

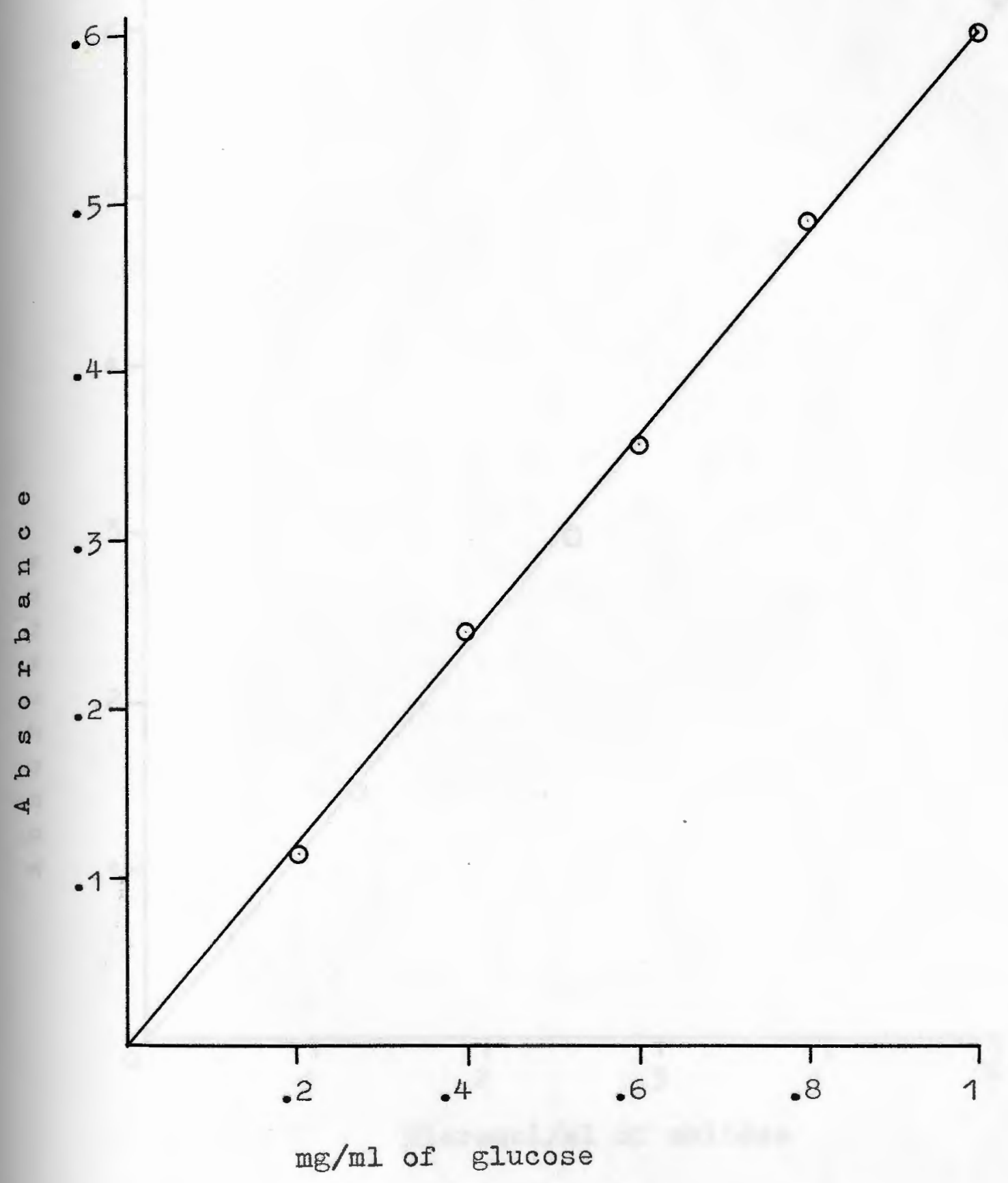

STANDARD FOR REDUCING SUGAR DETERMINATION WITH D N S. 
Page 24

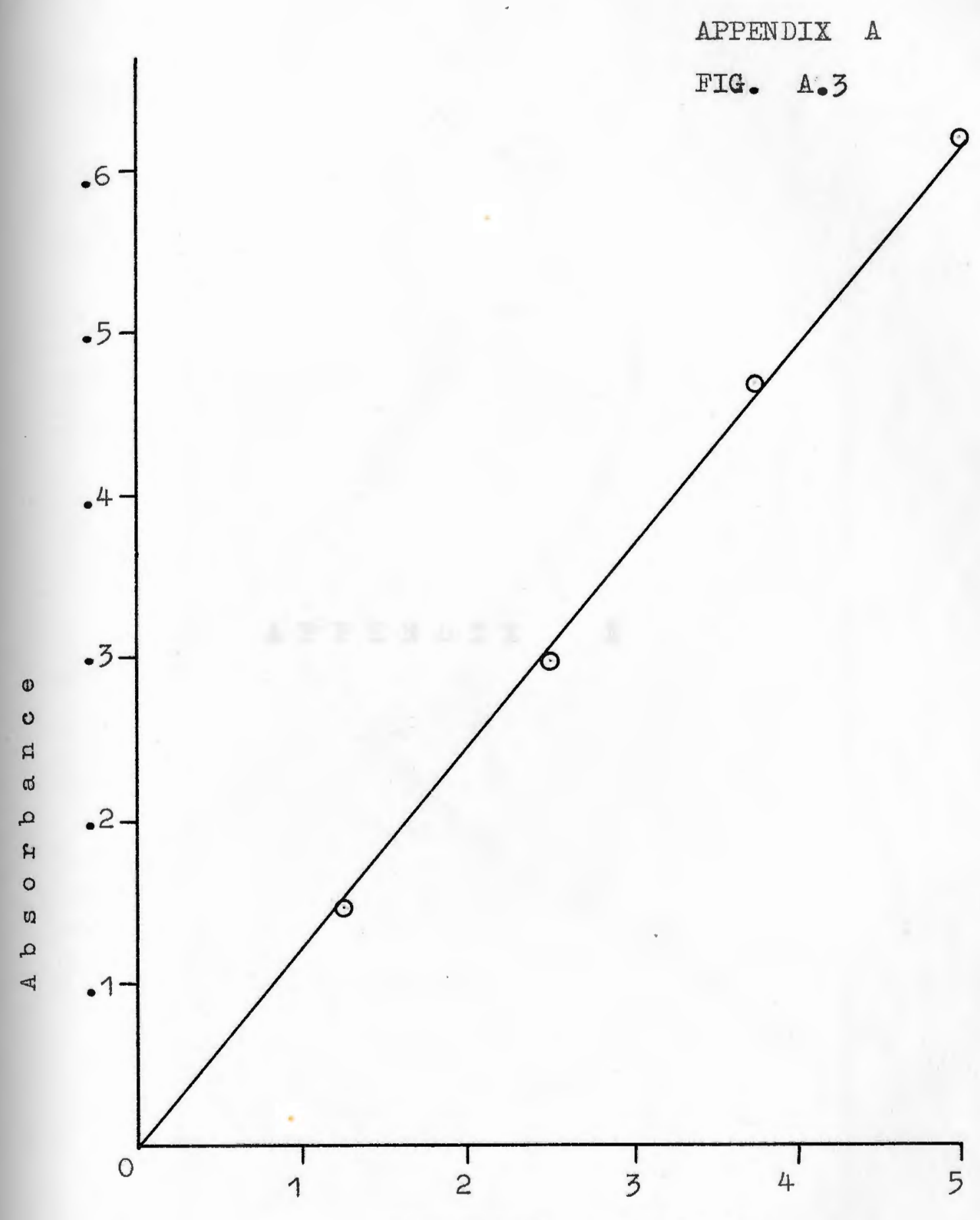

Micromol/ml of maltose

MAITOSE ASSAY. - STANDARD FOR ENZYME ANAIYSIS. 
A P P E N D I X

B 


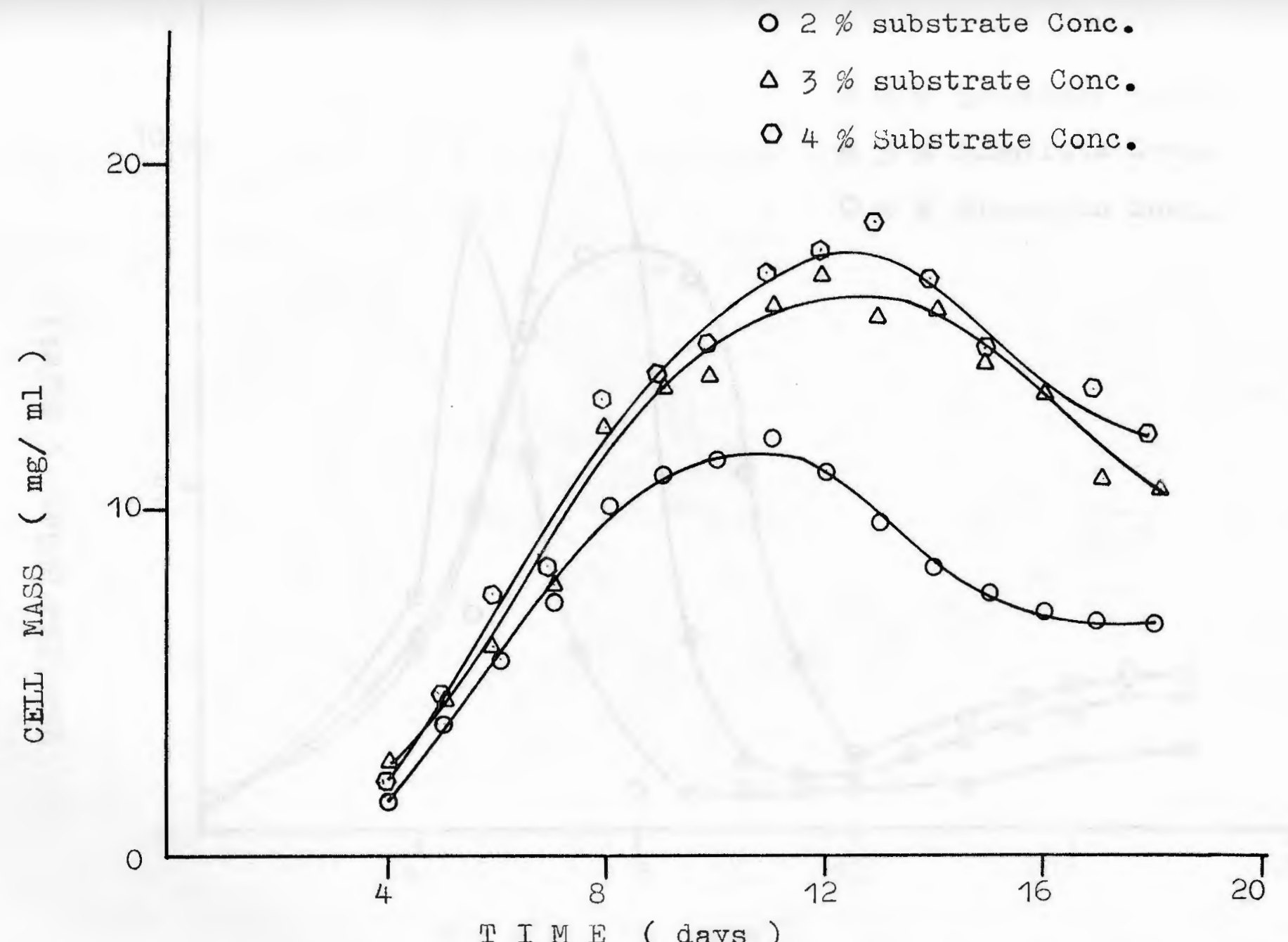

T I M E (days )

Fig. B.1.- Comparison of cell mass obtained at different substrate concentration. 









Fig. B.3.- Comparison of alpha-amylase activity at different substrate concentration. 


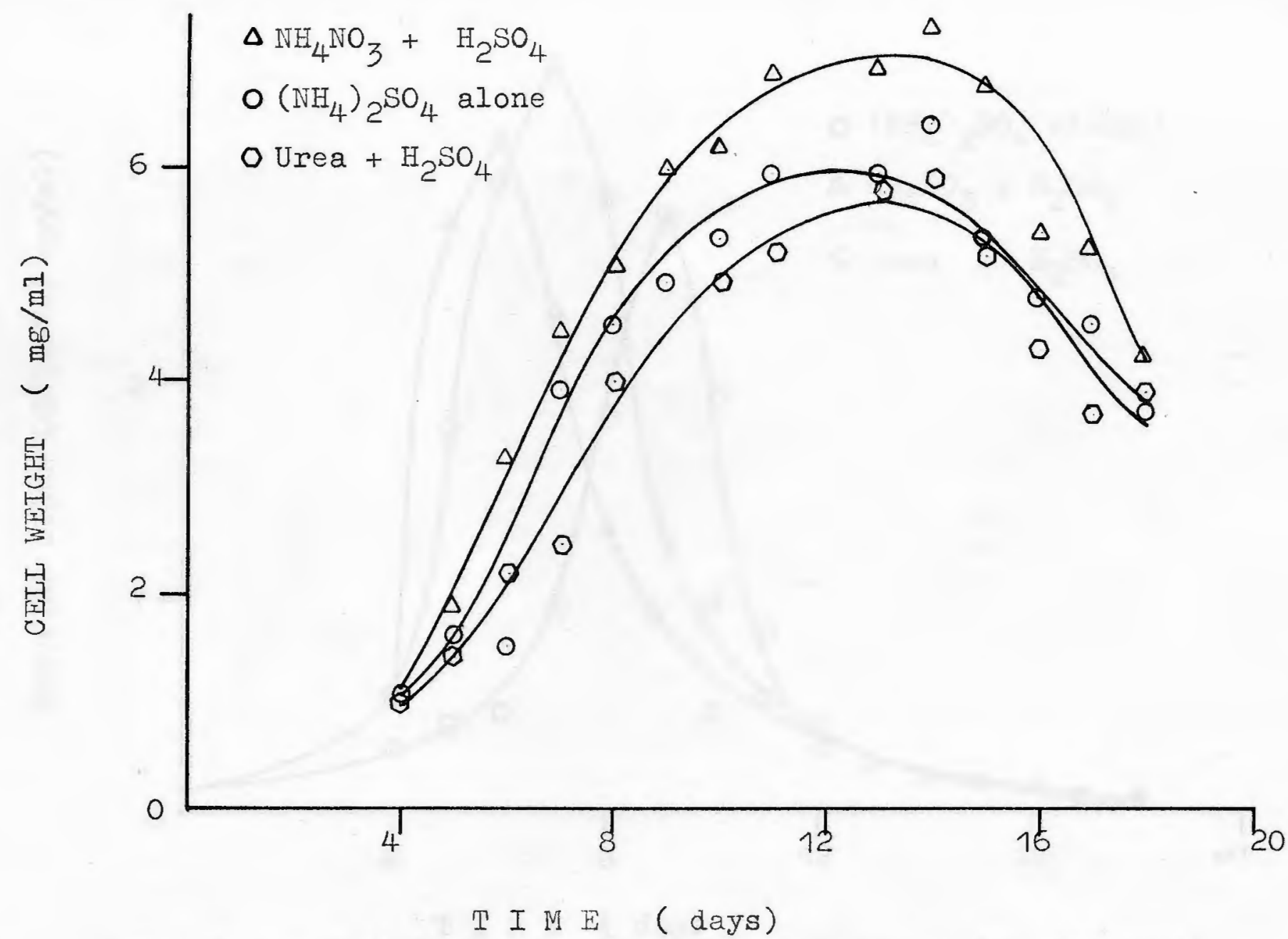

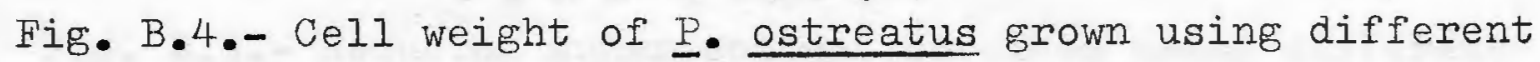
nitrogen sources plus sulfuric acid. 


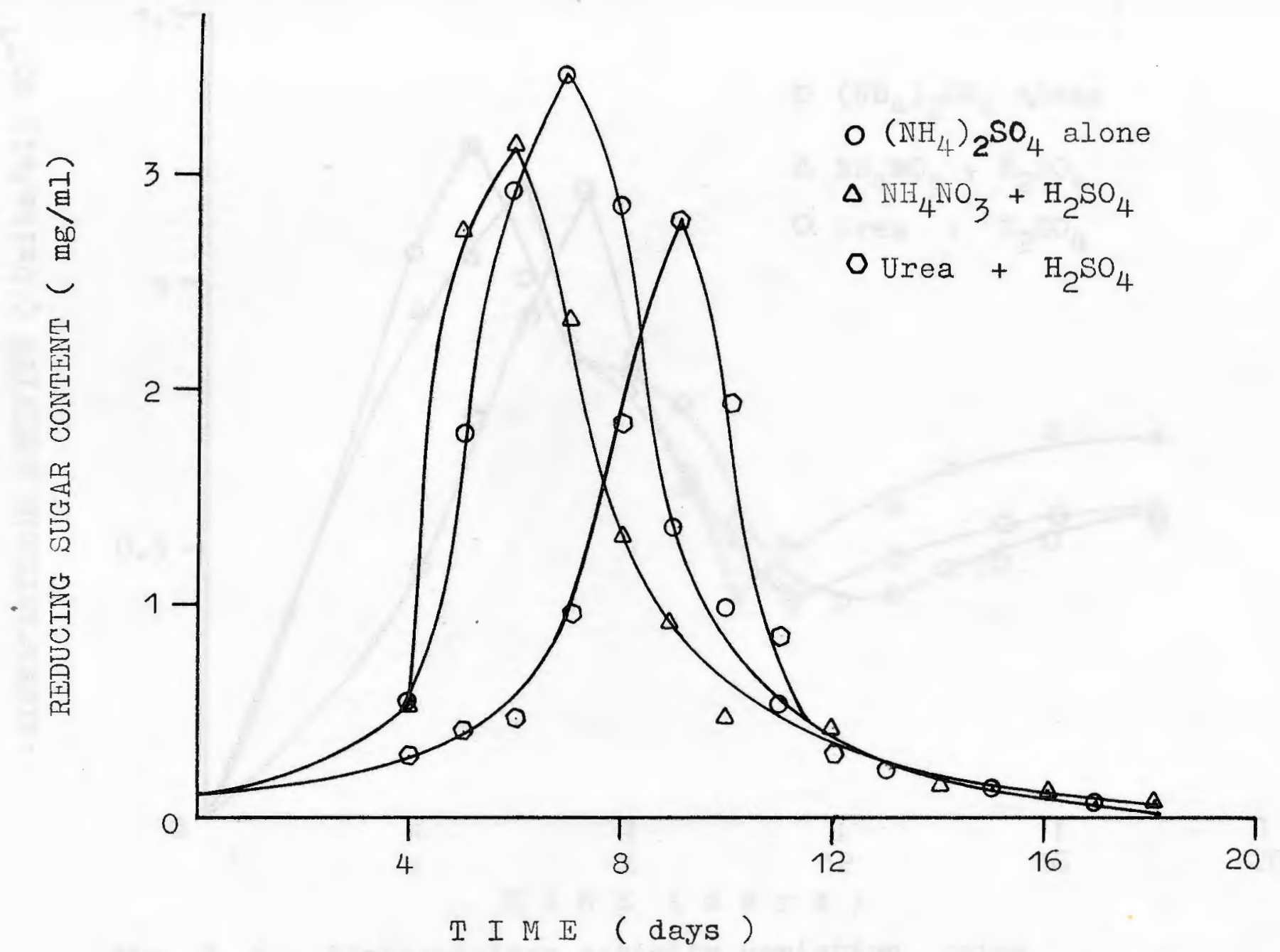

Fig. B.5.- Reducing sugar content obtained using different nitrogen sources plus sulfuric acid. 




F'ig. B. 6.- Alpha-amylase activity variation using different nitrogen sources and sulfuric acid. 


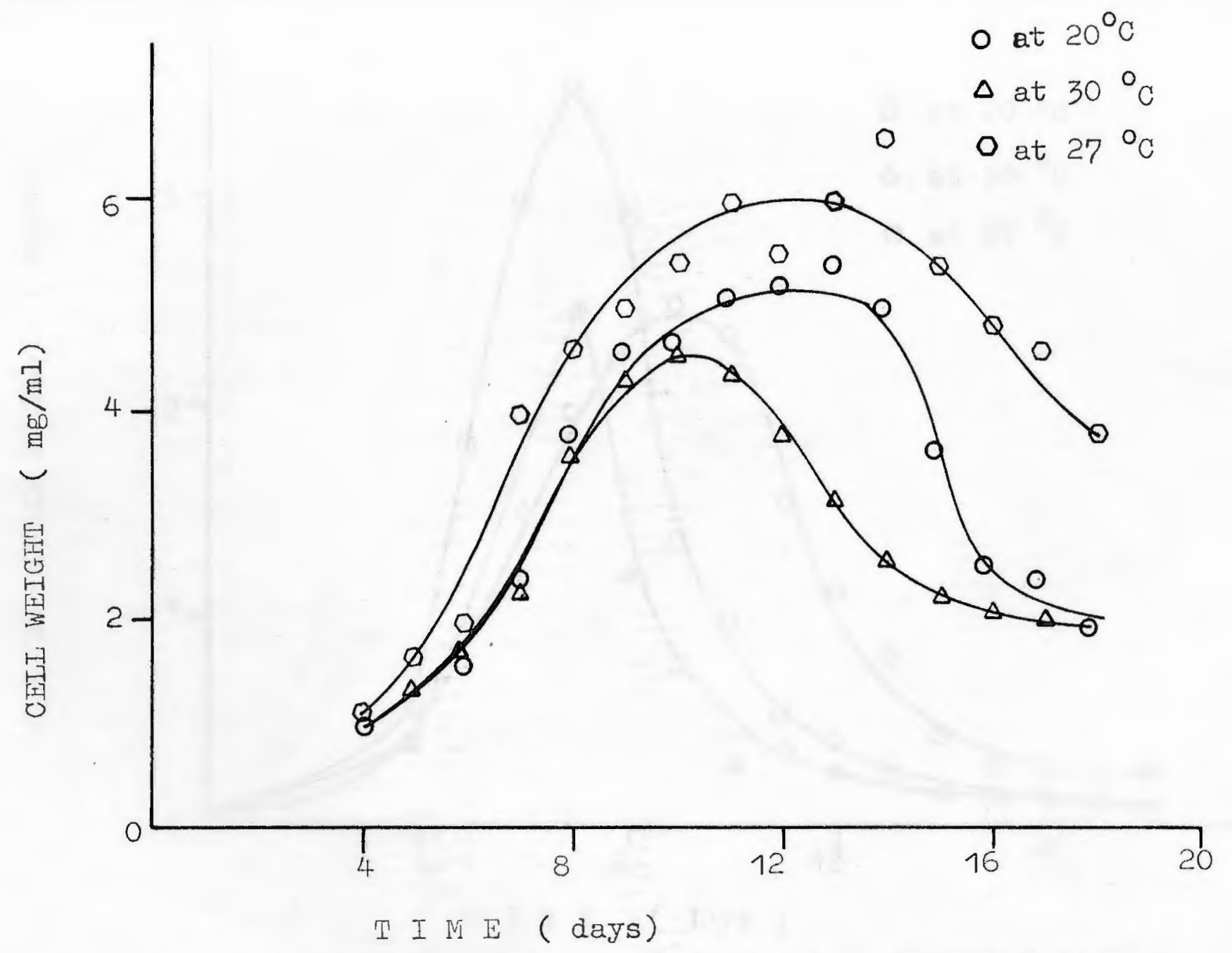

Fig. B.7.- Cell weight of $\mathrm{P}$ - ostreatus obtained at different temperatures. 


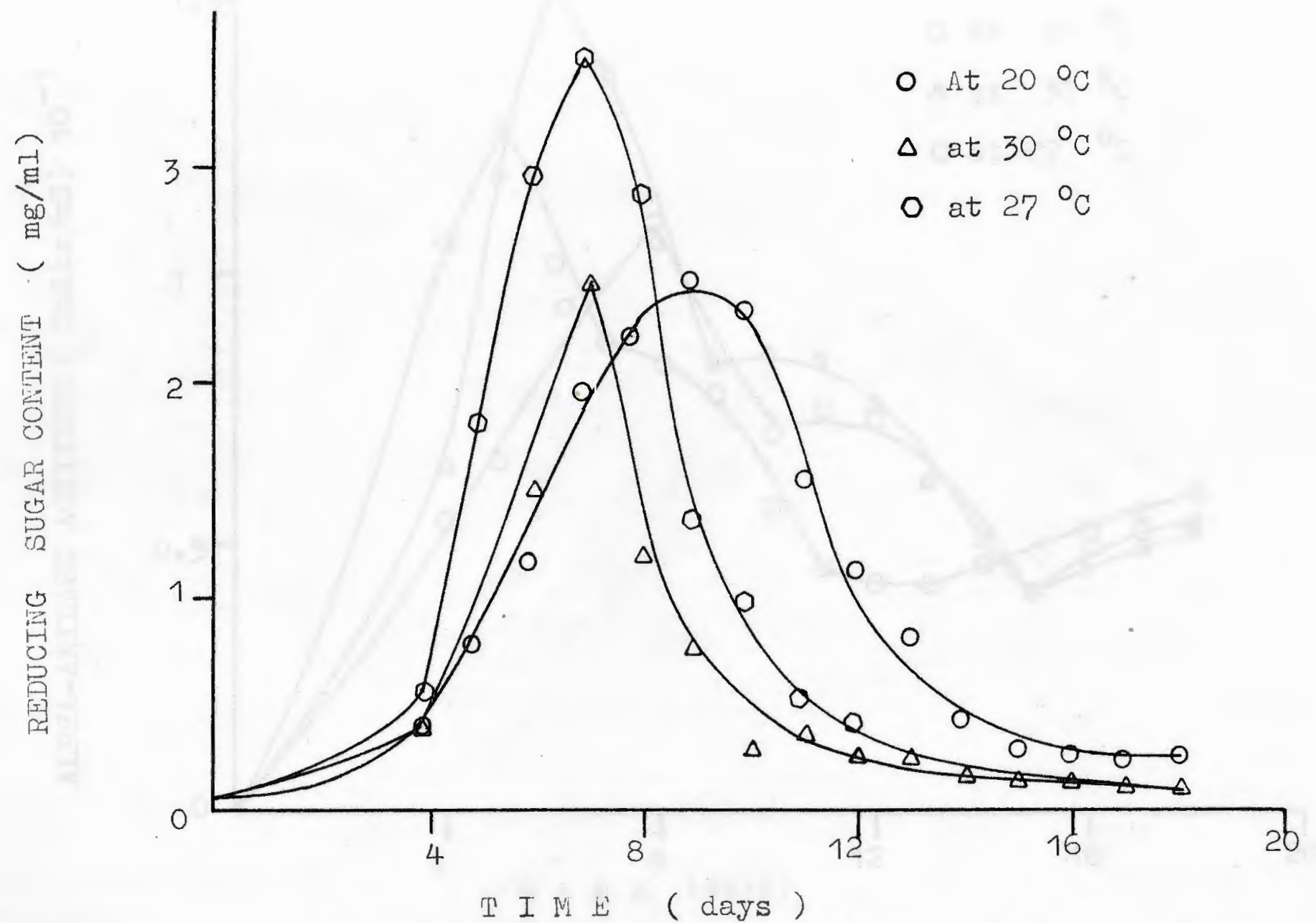

Fig. B.8.- Reducing sugar content variation at different temperatures. 


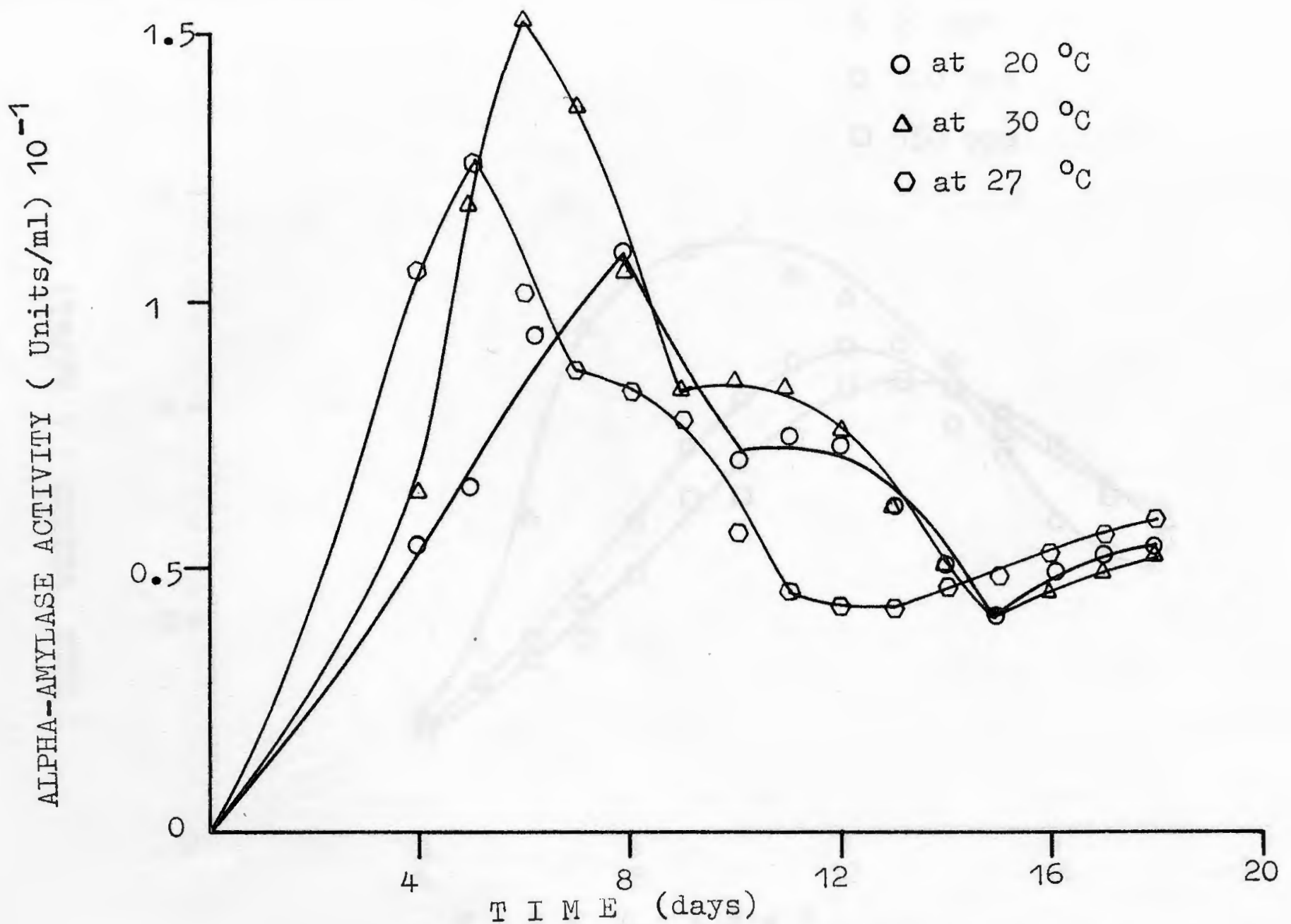

Fig. B. 9.- Alpha-amylase activity variation at different temperatures. 


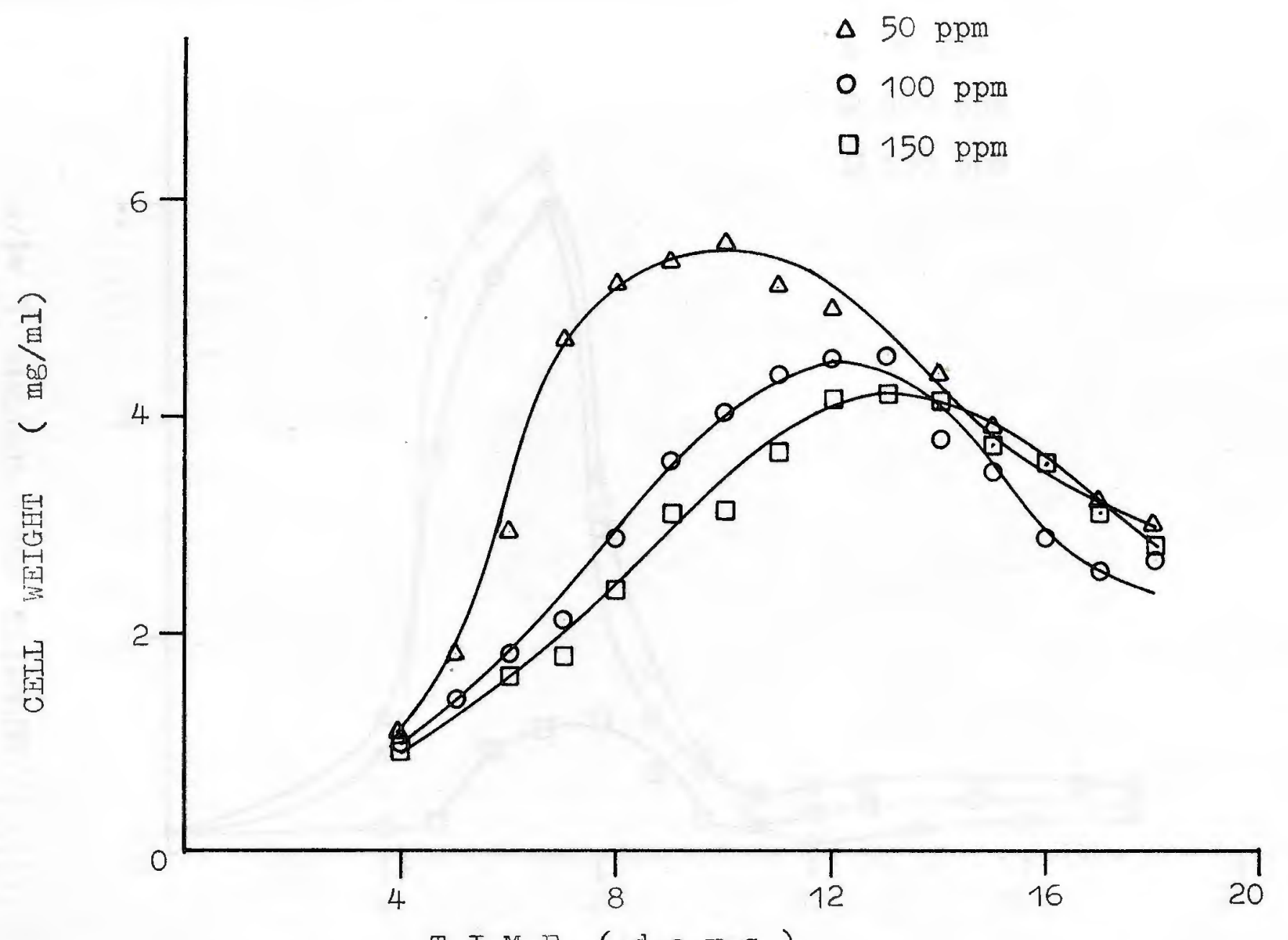

T I M $E$ ( d a y s )

Fig. B.10.- Cell weight variation of P. ostreatus grown at different concentration levels of sodium bisulfite. 


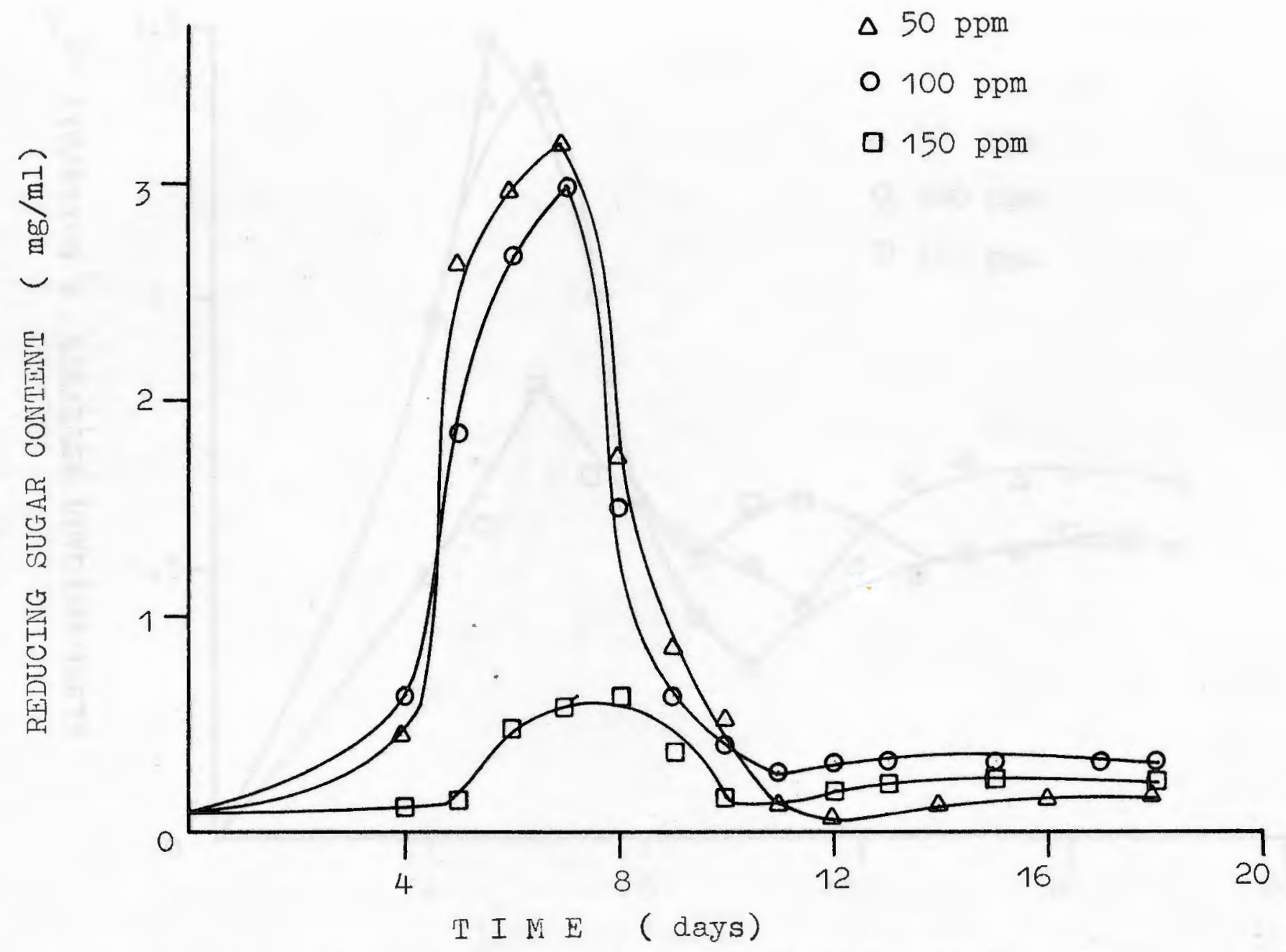

Fig. B. 11.- Reducing sugar content variation at different 


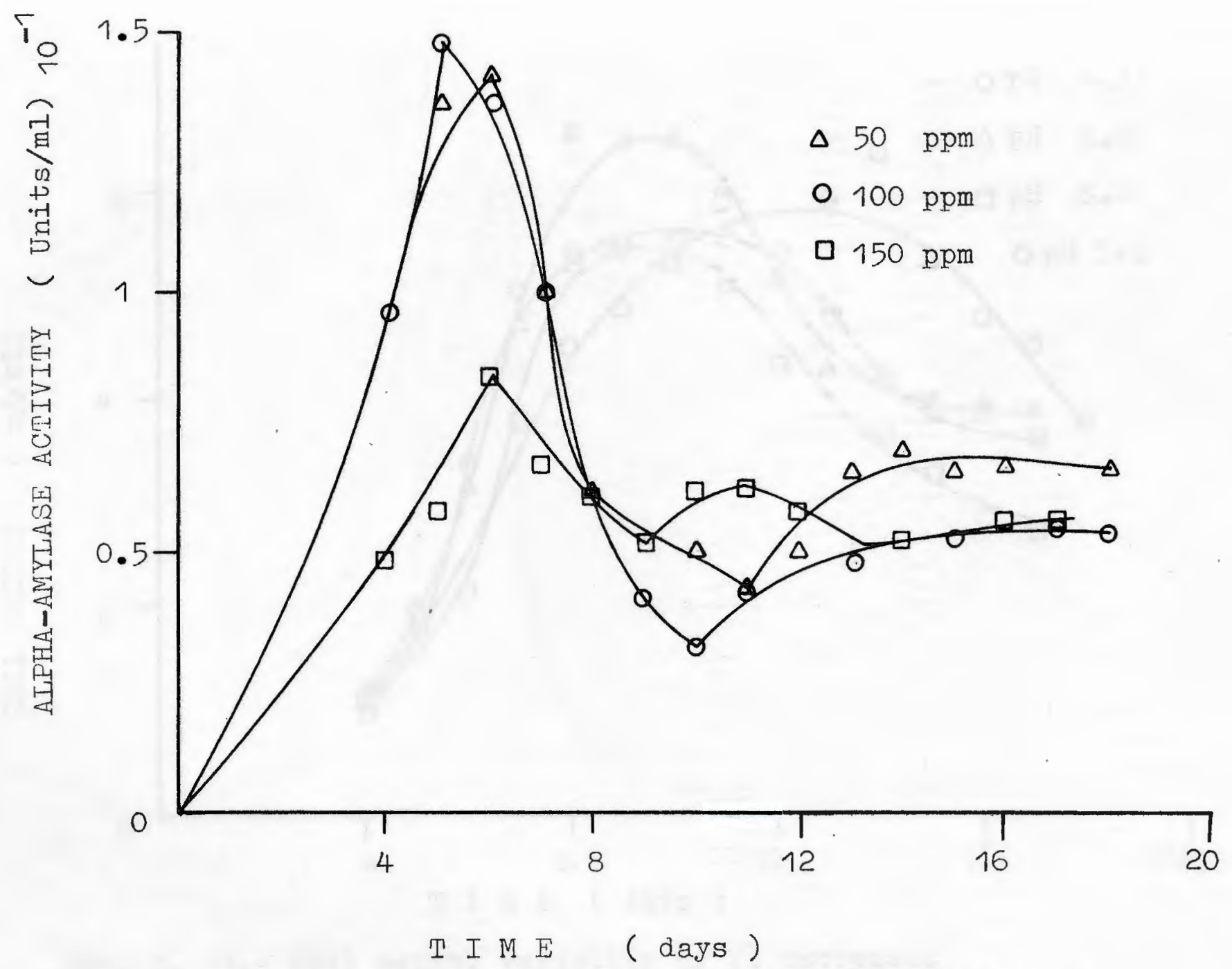

Fis. B. 12.-Alpha-amylase activity variation at different concentration levels of sodium bisulfite. 


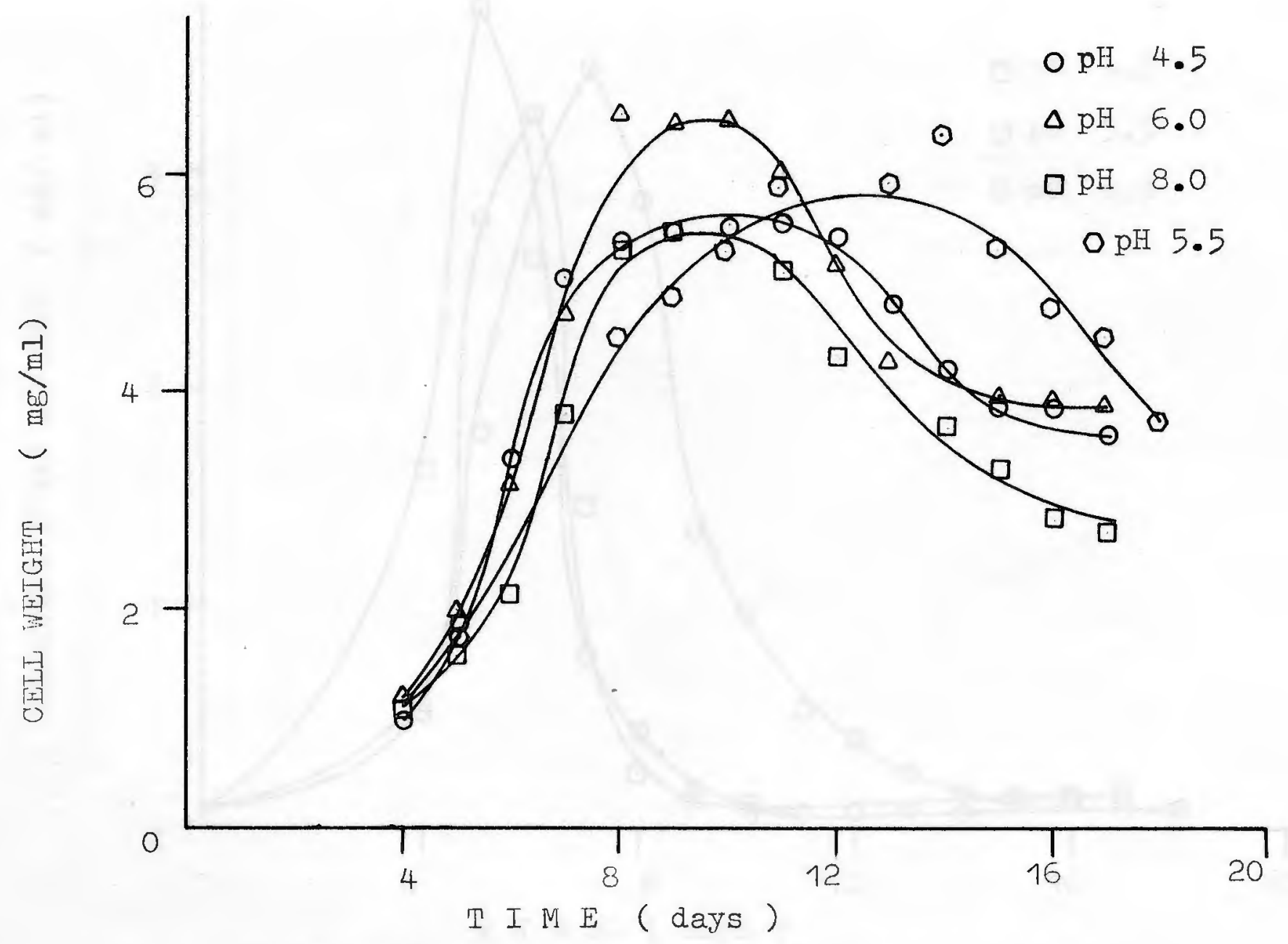

Fig. B. 13.- Cell weight variation of $\underline{P}$ - ostreatus at different pH values. 




Fig. B.14.- Reducing sugar content variation at different pH values. 




Fig. B. 15.- Alpha-amylase activity variation at different pII values. 